\title{
Maârif Salnâmelerine Göre Halep İdadisinde Eğitim (1898-1904)*
}

\section{Education in Aleppo High School According to the Yearbooks (1898-1904)}

\author{
Arş. Gör. Büşra ELÇIÇEĞi ${ }^{(D)}$, Prof. Dr. Ali YILMAZ ${ }^{(D)} 2$
}

$\ddot{\mathbf{O z}}$

Eğitim sisteminin niteliğini arttırmaya yönelik çalışmalar yapmak için öncelikle tarihimizi, sonra Türk eğitim sistemimizin yapısını çok iyi bilmek mecburiyetindeyiz. Halep, Osmanlı Devleti'ne bağlı eyaletler içinde üç yüzyıllık sürecin verilebildiği tek şehirdir. Bu nedenle İstanbul ve Kahire'den sonra dönemin üçüncü büyük ili kabul edilen Halep'in merkez sancağı araştırılmıştır. Maârif Salnâmeleri'ndeki bilgiler doğrultusunda bu çalışmada, Halep Mektep İdadisi'nde gerçekleştirilen eğitim-öğretim faaliyetleri incelenmiş̦tir. Araştırma nitel desende tasarlanmış olup doküman incelemesi tekniği kullanılarak betimsel analiz yapılmıştır. Bu amaçla H.1316-1321/M.1898-1904 tarihli salnâmeler incelenip Halep Sancağı'ndaki mevcut idadi, bu okuldaki idareciler, öğretmenler, okutulan dersler, öğrenci ve hademe sayıları ele alınmıştır. Ayrıca Halep'te bulunan medreseler, bulundukları yerler, medreselerde görevli müderrisler, öğrenci sayıs1, medresenin kurucusu, kütüphaneler, kuruluş tarihleri, kitap adetleri, kütüphanelerin kurucuları hakkında bilgi verilmiştir. Halep'te basın yayın faaliyetlerinin sürdürüldüğü matbaa ve gazetelerin bulunduğu mevkiler, sahip oldukları imtiyazlar ve hangi lisanlarda eser neşrettikleri hakkında bilgiler tespit edilmiştir.

Anahtar Kelimeler: Eğitim, idadi, kütüphane, medrese, basın-yayın

Makale Türü: Araştırma

\begin{abstract}
In order to increase quality of education system, we have to know our history and then structure of our Turkish education system very well. Aleppo is the only city within the provinces of Ottoman Empire that three-century process could yield. For this reason, central province of Aleppo, which is considered the third largest city after Istanbul and Cairo, was examined. In this study, educational and teaching activities carried out in Aleppo High School were examined in line with information in education yearbook. The study was designed in a qualitative design and descriptive analysis was performed using document analysis technics. For this purpose, yearbooks dated A.D.1316-1321 / C.E.1898-1904 were examined and current administration in sanjak of Aleppo, administrators in these schools, teachers, lessons taught, number of students and janitors were researched. In addition, information was given about madrasas in Aleppo, their places, mudarris in madrasas, number of students, founder of madrasah, libraries, dates of establishment, number of books and founders of libraries. Information about positions where printing presses and newspapers in Aleppo, privileges they have and languages in which they are published were confered.
\end{abstract}

Keywords: Education, high school, library, madrasah, press

Paper Type: Research

\footnotetext{
* Bu çalışma 07.11.2019-09.07.2019 tarihleri arasında Ankara Üniversitesi bünyesinde düzenlenen 8. Uluslararası Sosyal Bilgiler Eğitimi Sempozyumu'nda sözlü bildiri olarak sunulmuştur.

${ }^{1}$ Marmara Üniversitesi, Atatürk Eğitim Fakültesi, belcicegi@gmail.com.

${ }^{2}$ Marmara Üniversitesi, Atatürk Eğitim Fakültesi, ayilmaz@marmara.edu.tr.
} 


\section{Giriş}

Suriye'nin kuzeyinde bir vilâyet merkezi olan Halep, Firat ile Asi nehirleri arasında geniş bir ova üzerinde kurulmuş olup büyük bir kısmı sûrlarla çevrili, 9 kapısı, 155 cami, 164 mescidi, 23 medrese, 90 ilkokulu bulunan önemli bir yerleşim yeridir. Batısında Adana vilâyeti ve Akdeniz, güneyinde Trablusşam vilâyeti, güneybatısında Beyrût ve Suriye vilâyetleri, güneydoğusunda Zûr Sancağı, doğuda Musul, Rakka ve Bağdat, kuzeyinde Maraş, Antep, Elazı̆̆ ve Sivas vilâyetleri, kuzeydoğusunda Diyarbakır bulunmaktadır (Çakar, 2003; Çakar, 2006; Kılıç, 2016; Sami, 1306).

Halep şehri, XVII. asırda, Payas, İskenderun, Lazkiye, Trablusşam limanları ve Süveyde iskelesi ile Akdeniz'e, Anadolu ve Basra'ya açılma imkânı bulmuştur (Çakar, 2006; Göyünç, 1975; Heyd, 2000; Sedillot, 2005). Canlı bir ticaret güzergâhı olan Bağdat- Âna- Hit- Halep ve İpek yoluna ev sahipliği yapan şehir Fırat nehri ile Akdeniz'e eşit mesafede olması nedeniyle bu yolları birbirine bağlayan tek karayolu olma özelliği taşımaktadır (İnalcık, 2008; Masters, 2003; Oğuzoğlu, 2009; Sauvaget, 1967). Ayrıca demiryolu ile İstanbul ve Medine'ye bağlanmaktadır (Kılıç, 2016). Halep'in coğrafi konumundan dolayı Avrupalı milletlerin bölgeye ilgisi artmış ve başta İtalyanlar (Venedik) olmak üzere Fransa, İngiltere ve Hollanda şehirde konsolosluk açmıştır. İngiliz ve diğer yabancı tüccarların yerleşik düzen kurduğu tek iç bölge kentidir (Karakoç, 2013; Masters, 2003; Sauvaget, 1967).

Halep eyaleti, yaşama kabiliyeti, verimli tarım alanları, zeytin ve dut ağaçlarına sahip olması nedeniyle bölgenin ünlü sabun ve ipek kumaşı ihracatçısı olmuştur. Bölgede yaşayan halk kervan ticaretinin devamlılığı için yük hayvanı temini ve rehberlik faaliyetleri ile hizmet sektörünün öncüsü konumundadır. Çöl ile kent arasında kurulan ilişki Halep'in savunmaya uygun konumu ile dengelenmiştir (Halaçoğlu, 1997; Masters, 2003; Öztürk, 1997). Halep hakkında Sauvaget, Avrupalı gezginlerin coşkulu beğenilerinin asla abartılı olmadığını söylerken; D'Arvieux ise Halep'in Konstantinopolis ve Kahire'den sonra imparatorluğun en büyük, en güzel ve en temiz kenti olduğunu belirmiştir (Raymond, 1995).

Halep, böyle bir coğrafi konuma sahip olması hasebiyle tarih boyunca çeşitli uygarlıkların güç gösterisine sahne olmuş ve bu durum kentin farklı milletlerin egemenliği altına girmesine neden olmuştur. Tarih sahnesinde ilk kez M.Ö. 20. asırda görülen Halep, bir köy iken coğrafi konumu sayesinde çevresindeki yerleşim yerlerine hâkim olarak büyük bir yerleşim yerine dönüşmüştür (Sauvaget, 1967). Adı ilk olarak M.Ö. 3000 bin yıllarında Akad tabletlerinde geçen, dünyanın ilk yerleşim bölgelerinden biri olan Halep, M.Ö. 19. yüzyılda Hitit egemenliğinde görülmektedir (Yazıc1, 1997). Bölge sırasıyla Yamhad krallığı, Mitanni, Hurri, Mısır, Arami, Asur, İran ve Selevikler hâkimiyetine girmiştir. Halep, Romalılar döneminde kalesi ve kutsal yerleriyle Akrapolise dönüşmüştür. Bizans devrinde, çok sayıda kilisenin yer aldığı Hıristiyanlık merkezi olmuştur. Kent günümüzde başpiskoposluk ve Mârûnî piskoposluğudur. Hz. Ömer döneminde İslam ordusu tarafından feth olunmuştur (Çakar, 2006; Lammens, 1970; Yazıc1, 1997). İslamiyet dönemimde şehir Emeviler, Tolunoğulları ve Abbasilerin egemenliğinde yönetilmiştir (Brocekelman, 1992; Çakar, 2006; Merçil, 1997). Daha sonra bölgeye Karmatiler, İhşidler, Arap Beni Tağlîb kabilesinden olan Seyfü'd-Devle hâkim olmuştur (Ethem, 1927; Merçil, 1997; Sauvaget, 1967). Seyfü'd-Devle, Halep'i Hamdâniler'in başşehri yapmış (H.333/M.944) ve bu tarihten itibaren şehir bölge tarihinde önemli bir misyona sahip olmuştur. Seyfü'd-Devle'nin vefatı sonrasında elli yıl boyunca Halep'te Bizans saldırıları, Bedevi yağmaları ve Fatimilerin mücadeleleri sonucunda istikrar sağlanamamıştır. Bedevi kabilelerin 1022 'de Suriye'yi aralarında taksim etmeleri sonucunda Halep, Beni Kilab kabilesinden Salih b. Mirdas'ın hâkimiyetine girmiştir (Brocekelman, 1992; Ethem, 1927; Iş11tan, 1966; Ostrogorsky, 1986; Yazıc1, 1997).

Sultan Alparslan Mısır seferi sırasında şehri Selçuklulara bağlamıştır. Halep en parlak dönemini Selâhaddin Eyyûbi'nin oğlu, Melik Gazi döneminde yaşamıştır (Çakar, 2006; Sauvaget, 1967; Yazıc1, 1997). Orta çağda, Halep'in geleceğinin üst seviyelere ulaştığı devir Eyyubiler 
dönemi olmuştur. Halep şehri, 1207, 1225, 1229 ve 1254 senelerinde gerçekleştirilen ticaret anlaşmaları sayesinde daimî ticaret merkezi açma hakkı elde eden Venedikliler ile yapılan ticaret sonucu zenginleşmiştir (Heyd, 2000; Sauvaget, 1967). Hülâgu 1260 yılında, altı gün şehri yağmalayarak katliam yapmıştır (Grausset, 1980; Yazıc1, 1997). Ayn-Calut savaşında Moğollar yenilerek Memlûklu egemenliği Suriye'de sağlanmıştır (Köprülü, 1961; Yazıc1, 1997). Memlukler tarafından Suriye altı idari bölgeye ayrılmış ve bu bölgelerden biri Halep olmuştur (Lammens, 1970). Merc-i Dâbık savaşında Memlükler mağlup edilerek bölge Osmanlı egemenliğine girmiştir (Çakar, 2006; Tansel, 1969; Uzunçarş111, 1975). Yavuz Sultan Selim Halep'lilerin isteği üzerine şehrin yağmalanmasına izin vermemiştir (Tansel, 1969). Osmanlı hâkimiyetinde önce Şam beylerbeyliğine bağlı sancak konumuna dönüştürülen Halep Şam valisi Canberdi el-Gazali'nin ayaklanma çıkarmasının ardından M.1549'da İstanbul'a bağlı müstakil bir beylerbeyliğine dönüştürülmüştür. Şam ve Halep'e Türkçe konuşan valiler atanarak tımar sistemi kurulmuştur (Çakar, 2003; Masters, 2003). Şehir M.1897-1898 yıllarında yapılan düzenlemeler ile Halep vilâyeti, merkezi Halep olmak üzere Maraş ve Urfa dâhil üç sancak ve onlara tabii 23 kaza, 64 nahiye ve 4.541 köyden meydana gelmiştir (Bayraktar, 2004; Cevdet Paşa, 1991; Düvenci, 2013). Kent en parlak dönemini Osmanlı Devleti döneminde 15.-18. Yüzyıllar arasında yaşamıştır (Sauvaget, 1967). I. Dünya Savaş1 öncesinde diğer bölgelerde olduğu gibi Halep'te Arapçı faaliyetler görülmemiş ve Halepli gençler Osmanlı ordusuna katılarak devlete olan bağlılıklarını göstermişlerdir. Osmanlı Devleti 1918 yılında fiilen yıkıldığında Hıristiyan ve Yahudi halk Fransız mandası yanlısı bir tutum sergilerken bir kısmı Faysal'ın Arap Krallığı'ndan yana olmuştur. Müslümanlar ise Mustafa Kemal öncülüğünde kurtuluşu arzu etmişlerdir. Halep'in 1920 yılında Fransızlar tarafından işgal edilmesi üzerine İbrahim Hannanu liderliğinde direniş başlarken Halepliler sessiz kalarak Fransız mandasında kentin eyalet başkenti olmasına rıza göstermişlerdir (Babuçoğlu, Eroğlu ve Köçer, 2007; Masters, 2003). Halep günümüzde Suriye'nin 14 idari bölgesinden birini oluşturmaktadır (Çakar, 2006; Umar, 2003; Umar, 2004).

Halep'te etnik yapı olarak İslamiyet, Hiristiyanlık ve Musevilik dinine mensup olan kişiler, Avrupalılar, Yakubi Hristiyanlar, Maruniler, Rumlar, İranlı Ermenilerin yanında Kuzey Afrikalı, Hindistanlı ve Buharalı tüccarlar bir arada yaşamıştır. Farklı milletlerin yaşaması Arapça, Türkçe, Ermenice, İspanyolca ve Farsça'nın konuşulduğu dil çeşitliliğine neden olmuştur. Halep'in nüfusu, 16. yüzyıl sonlarında merkez sancak olarak (Nefs-i Şehir) 30 bini, eyalet olarak ise nüfusu 200 bini aşmıştır. Şehrin 17. yüzyıla gelindiğinde nüfusu 120 bine ulaşarak İstanbul ve Kahire'den sonra en büyük üçüncü şehir merkezi olmuştur (Masters, 2003; Öztürk, 1997). Bu yüzyıl sonunda mahalle sayısı ise 72'dir (Raymond, 1995). 1885 tarihli salnâmede yer alan bilgiler doğrultusunda kentte; 72.155 Müslüman, 21.051 Hristiyan, 7.790 Yahudi ve 153 Ecnebi olmak üzere toplam 101.149 insan ikamet etmiştir (SVH, 1303, s.158). Halep Vilâyeti'nde 1890'larda 110 mahalle olup toplam 106.313 insan yaşamıştır. Nüfus Nezareti verileri doğrultusunda 1896-1897 yılında Halep merkez sancağının nüfusu 100 bine, eyalet geneli 816.057 kişiye ulaşmıştır (SVH, H.1314, s.157, 181).

Halep'in toplumsal hayatında erkeğin yanında kadınında rol aldığı görülmektedir. XVIII. yüzyıla ait bazı kayıtlarda Halep'in, eski valisi Kara Mustafa Paşa'nın kızı Abide Hanım'ın babasının kurduğu vakfın hanını yönettiği; avarız defterlerinde 136 kadının hane reisi olarak kaydedildiği görülmektedir (Masters, 2003; Öztürk, 1997; SVH, H. 1312, s.121). Ayrıca kentin, basınla erken tanışarak Osmanlı Devleti'nin Arapça ilk basımevine sahip oluşu (1706) coğrafyadaki diğer şehirlerden kültürel ayrıcalığıdır (Masters, 2003; Raymond, 1995). Yönetimin zayıfladığı devirlerde Halep eyaletinde bazı ayaklanmalar ve iç huzursuzluklar görülmesine rağmen bu olaylar etnik veya dini temelli farklılıklardan kaynaklanmamıştır (Tutar, 2010). Halep Müslümanlarının, Avrupalı ziyaretçilere ve Gayrimüslim halka hoşgörü ile muamele ettiklerine örnek olarak, Fransız Constantine Volney'in şu yorumu verilebilir: "Türk ya da Hıristiyan olsun kentin halkı, layık oldukları üzere, tüm Türkiye'nin en uygar unsurları olarak takdir edilmektedir. Bundan dolayı Avrupalı tüccarlar böylesi özgürlüğü ve sayg1lı yaklaşımı hiçbir yerde görmemiştir" (Masters, 2003, s.52). Türk eğitim tarihi çalışmaları geçmiş ile günümüz arasında 
bağ kurmamızı sağlaması açısından önem arz etmektedir. Gerçekleştirilen literatür taramasında Osmanlı Devleti döneminde mevcut vilâyetler arasından genel olarak Türkiye sınırları içerisinde yer alan bölgelerin çalışıldığı gözlenmiştir. Bu çalışmalar içerisinde de eğitim tarihi alanına yönelik çalışmaların ihmal edildiği saptanmıştır.

Türkçeye Tanzimat devrinden sonra giren salnâmeler; bir yıllık süreç boyunca yaşanan olayları ve değişiklikleri göstermek için hazırlanan eserlerdir. Kelime köken olarak Farsça "sene" manasına gelen "sal" ile mektup, kitap manasında kullanılan "name" sözcüklerinin birleşimi ile oluşturulmuştur. Bu kelime günümüzde "yıllık" kelimesine karşılık gelmekte olup Osmanlı salnâmeleri, içeriğinde devletin ve vilâyetlerin tarihi, coğrafyası, nüfusu, idari, askeri, hukuki teşkilatları, ekonomik durumu ve eğitim yapısı hakkında bilgiler yer almaktadır (Pakalın, 1983 s.105-106, Palalı, 2010, s.1-14). Maârif Nezareti tarafından çıkarılan salnâmelerde, nezâretin tarihçesi, nazırları, memurları, ülkedeki medreseler, müderrisler, Müslüman, Gayrimüslim ve ecnebi okullarının isimleri, öğrenci sayıları, kuruluş ve ruhsat tarihleri, kütüphaneler, kitap sayıları, kurucularının adlarına dair bilgiler bulunmaktadır. Bu nedenle eğitim tarihi ile ilgili çalışmalarda kaynak eser niteliğindedir. II. Abdülhamit döneminde Maârif Nezareti, M.18941895 yılından itibaren, ilk defa ülke genelinde eğitim istatistikleri; M.1898-1904 yılları arasında da Salnâme-i Nezaret-i Maârif-i Umumiye adıyla eğitim-öğretim yıllıkları yayınlanmıştır. Mevcut belgeler, ülke genelindeki eğitim durumunu istatiksel olarak ve toplu biçimde gösterdikleri için, eğitim sorunlarının daha iyi anlaşılıp değerlendirilmesine yardımcı olmaktadır (Akyüz, 2019). "Maârif Salnâmelerine göre Halep İdadisinde Eğitim (1898-1904)" konusunun araştırılmasında salnâmelerde konuya ilişkin kıymetli bilgilerin olması etkili olmuştur. Halep mektep idadisindeki, öğretici kadro, öğrenci sayıları hakkında bilgiler verilmiştir. Ayrıca Halep’te bulunan matbaa ve gazeteler hakkında elde edilen bulgular sunulmuştur.

\section{Yöntem}

Araştırma nitel araştırma desenine uygun olarak tasarlanmıştır. Nitel araştırma yönteminin tercih edilmesinde bu yöntemin belirli durumları yorumsamacı yaklaşım ile araştırmaya olanak vermesi etkili olmuştur (Büyüköztürk vd, 2012).

\subsection{Veri Toplama Araçları}

Araştırmanın amacı doğrultusunda verilerin toplanmasında doküman incelemesi tekniği kullanılmıştır. Doküman incelemesi, araştırılması hedeflenen olgu ya da olgular hakkında yazılı bilgi içeren her türlü kaynağın analiz edilerek çözümlenmesine dayalı bir tekniktir (Şimşek ve Yıldırım, 2011). Çalışmanın veri kaynağını H.1316-1321/M.1898-1904 tarihli Maârif Salnâmeleri oluşturmaktadır. İSAM aracılı̆̆ı ile ulaşılan Maarif Salnâmelerinin, Osmanlıca Türkçesinden günümüz Türkçesine çevirisi yapılmıştır. Halep Sancağı'ndaki mevcut idadi, bu okuldaki idareciler, öğretmenler, okutulan dersler, öğrenci ve hademe sayıları ele alınmıştır. Ayrıca Halep'te basın yayın faaliyetlerinin sürdürüldüğü matbaa ve gazetelerin bulunduğu mevkiler, sahip oldukları imtiyazlar ve hangi lisanlarda eser neşrettikleri hakkında bilgiler verilmiştir. Bunun yanı sıra konu ile ilgili kitap, makale, tez ve müfredattan yararlanılmıştır. Bu amaçla Marmara Üniversitesi ve İSAM kütüphane katalogları, veri tabanları, Google Akademik, Ulusal Tez Merkezi'nden faydalanılmıştır.

\subsubsection{Veri Analizi}

$\mathrm{Bu}$ çalışmanın verilerine erişimde doküman analizi tekniği kullanılmıştır. Doküman analizi, dokümanlara ulaşma, dokümanların orijinalliğini kontrol etme, dokümanları anlama, veriyi analiz etme ve veriyi kullanma olmak üzere beş aşamadan meydana gelmektedir. Buna göre; araştırmanın ilk aşamasında İSAM'dan elde edilen salnâmelerin Türkiye Türkçesindeki tercümesi yapılmıştır. Marmara ve İSAM kütüphanesi, veri tabanları, ulusal tez merkezi, Google akademiden ulaşılan eser, tez ve makaleler okunmuştur. İkinci aşamada dokümanların orijinalliği teyit edilmiştir. Üçüncü ve dördüncü aşamada, dokümanların anlaşılması için belgeler belirli bir sistem içinde birbirleriyle karşılaştırmalı olarak analiz edilmiş̧ir (Şimşek ve Yıldırım, 2011). 
Verilerin analizi betimsel analiz yöntemi ile gerçekleştirilmiştir (Büyüköztürk, 2012). Betimsel analiz gözlem, görüşme, doküman vb. veri toplama araçlarından elde edilen bilgilerin analiz edilmesine dayanmaktadır. Ayrıca incelenen konu hakkında yararlanılan kaynaklardan doğrudan alıntı yapılmasına olanak verir (Ekiz, 2013).

\subsection{Araştırmanın Sınırlııkları}

Çalışma erişilen beş Maârif Salnâmesi ile sınırlı tutulmuştur.

Halep Mektep İdadi’sindeki idareciler, öğretici kadro, okutulan dersler, öğrenci-hademe sayıları, basın-yayın faaliyetleri ile sınırlıdır.

Araştırma kaynakçada belirtilen kitap, tez, makale ve salnâmeler ile sınırlıdır.

\section{Bulgular}

\subsection{Osmanlı Devleti’nde İdadi Okulları}

Arapça, hazırlamak, geliş̧tirmek anlamında "idad” kökünden türeyen idadi sözcüğü hazırlama yeri demektir. 1869 yılından önce çoğu okulun hazırlama sınıfı idadi olarak adlandırılmıştır. Maârif-i Umumiye Nizamnamesi ile ilk kez başlı başına orta öğretimin kademesi olarak değerlendirilmiştir. Böylece idadi kavramı eski anlamını yitirerek yeni bir mahiyet kazanmıştır. Bu nizamname ile idadi okulları ile ilgili hususlar şu şekilde belirtilmiştir: 1) Rüşdiyelerden mezun olan Müslim ve Gayrimüslim çocukların beraber eğitim aldığ 1 yer idadi okullarıdır. 2) Bulundukları yerin önem derecesine göre seçilen ve nüfusu 1.000 haneden fazla olan kasabalarda idadi okulu açılacaktır. 3) Bu okulların masrafları vilâyet maârif idaresi sandığından temin edilecektir. 4) Her idadide muavinlerle beraber 6 öğretmen olacaktır. 5) Bu okulların yıllık ödeneği, personel masrafları dâhil 80.000 kuruş olacaktır. 6) Öğretim süresi 3 yıl olup şu derslerin eğitimi yapılacaktır: Türkçe kitâbet ve inşa, Fransızca, Kavâinin-i Osmaniye, Mantık, İlm-i servet-i milel, Coğrafya, Tarih-i umumî, İlm-i Mevâlid, Cebir, hesap ve defter tutma, Hendese ve İlm-i mesâha, Hikmet-i tabiyye, Kimya ve Resim. 4 yıl süren rüşdiye eğitiminden sonra 3 yil eğitim veren okullar idadilerdir. Nizamname'de bu okullar rüşdiyelerin üstünde, sultanîlerin altında kabul edilir (Baltacı, 2002, Öztürk, 2000). Okulların yapım masrafları, öğretmen ve hademe maaşları Vilâyet Maârif Sandığından karşılanacaktı. Bu okullarda muavinlerle birlikte 6 öğretmen bulunacaktı (Ergin, 1977; Hayta, 1995; Koçer, 1991; Kodaman, 1980).

Taşrada bulunan idadiler öğretim sürelerine göre beş ve yedi yıl olarak ikiye tasnif edilmiştir. İdadilerin iki türü de rüşdiye sınıflarını içermekteydi. Yedi yıllık leyli idadilere ücretli ve ücretsiz öğrenci kaydı yapılmaktadır. İdadiler 1869 nizamnamesine göre yönetilmiştir. 1892 tarihinde, talimatname hazırlanmış ve müdürlerin, muavinlerin, mubassırların görevleri, öğrenciler ile ilgili konular bir karara bağlanmıştır. H.1321/M.1904 numaralı Maârif Salnâmesi verileri doğrultusunda; taşrada 1896'da 54 idadi 7.644 öğrenci, 1901'de 68 idadide 11.445 öğrenci, 1906'da 93 idadi ve imparatorluk genelinde 109 idadi bulunmaktadır. 1909 tarihinde idadilerde 20.000 dolaylarında öğrenci öğrenim görmüştür (Ergin, 1977; Hayta, 1995; Kodaman, 1980).

\subsection{Halep Mekteb-i İdadisi}

Halep'te 1885 tarihinde idadi açılmasına karar verilerek yapımına başlanmıştır. Halep Vilâyeti'nde 1898-1904 yılları arasında bir adet idadi düzeyinde okul bulunmaktadır. Bu okul, Osman Paşa Vakfı arsasının Maârif tarafından kiralanması üzerine inşa edilmiştir. İnşa edilen idadinin M. 1888 yılında 1.200 kuruş olarak belirlenen kira bedeli 1905 'ten sonra ülkenin içinde bulunduğu ekonomik sebeplerden dolayı ödenememiştir. Halep mütesellimi olan Osman Paşa, 1730 y1lında vezaret rütbesinin verilmesiyle Trablusşam, Sivas, Şam ve Halep'te (1737) valilik yapmıştır. Fakat dönemin koşullarınca yerine vekil gönderme uygulaması ile Halep'e hiç gitmemiştir (Yaslıçimen, 2018). İdadîler, Fransız okullarının mimarî usulüne göre yapılmıştır (Kodaman, 1980). Said Paşa'nın hazırlattığı planlara göre, idadilerin içinde 7 derslik, laboratuvar, 
kiler, hamam bulunmaktadır. Halep Mektep İdadîsinin, başlangıçta üç katlı yapılması plânlanmışsa da ekonomik ve siyasi sıkıntılar nedeniyle 2 katlı olarak inşa edilmesine karar verilmiştir. Plana göre 300 talebenin eğitim alabileceği, hamam, mutfak ve çamaşırhane gibi ihtiyaçlara cevap verebilecek düzeyde yapılması tasarlanmıştır. Halep Mekteb-i İdadîsinin gündüzlü eğitim vermesi kararlaştırılmış, fakat idadi M.1892 yılında yatılıya çevrilmiştir. İdadî öğretici kadrosu, araç-gereçlerinin tamamlandığı ilk etapta 70 öğrenci ile eğitim-öğretim faaliyetlerine başlamıştır. Açılış yılı ihtilaflı olsa da M.1890'da açılıp eğitim faaliyetlerine M.1892'de başlandığı düşünülmektedir. İdadînin adı ilk kez M.1892 vilâyet salnâmesinde geçmiş olup M.1893 yılında programına ilişkin bilgilere ulaşılmaktadır. Buna göre, M.1893'te 55 öğrencisi bulunan idadide görevli hocalar ve sorumlu oldukları dersler şu şekildedir: Müdür, Tarih-i Umumî ve Tıbbiye Muallimi: Abdi Bey, İmam ve Mübassır: Şeyh Mehmet Ferit Efendi, Arabî Muallimi: Abdullah Efendi, Resim Muallimi: Hayri Bey (Yüzbaşı), Farisî Muallimi: Naci Efendi, Mübassır: Osman Efendi, Lisan-i Osmanî Muallimi: Ahmet Hamdi Efendi, Hendese, Fransızca ve Hesap Muallimi: Liyan Efendi. Ayrıca idadînin içerisinde gerekli malzemelerin temin edilmesi için bir eczane açılmış ancak eczacı başının maaşı ödenemediği için kapatılmıştır. Aynı şekilde bakkal dükkânının açıldığı ve bir süre sonra kirası karşılanamadığı için kapatılmak durumunda kalmıştır (Yaslıçimen, 2018).

Maârif ve Vilâyet Sâlnâmelerine göre 1898 yılında Halep'in eyalet bünyesinde mevcut 6 memuriyeti ve idarecileri şu şekildedir: Maârif Müdürü: Hüsnü Zeki Bey, Maârif Muhasebe Memuru: Ali Rıza Efendi, Maârif Kâtibi: Necib Efendi, Matbuat-1 Ecnebiye Muayene Memuru: Fettah Efendi, Maârif Muhasebe Memuru: Refiki Şakir Efendi ve Maârif Sandık Emini: Ahmed Rıza Efendi. Maârif Sâlnâmesinde 1899 yılındaki Maârif Kâtipliği isim değişikliğine gidilerek İdare Kâtipliği'ne dönüşmüştür. Maârif İdaresinin 1900 y1lında Müdürlüğüne Mahmud Celaleddin Bey, Matbuat-1 Ecnebiye Muayene Memurluğuna Habip Raşid Efendi ve Sandık Eminliğine Necip Efendi getirilmiştir. 1904''te ise Mahmud Celaleddin Beyin 6 Nisan 1896 tarihinde Maârif Müdürü olduğu görülmektedir (Görür, 2016). 1898-1904 yılları arasında Halep Mekteb-i İdadisi'nin ögretici kadrosu ve okutulan dersler ile ilgili bilgiler Tablo 1'de verildiği gibidir.

Tablo 1. H.1316-1321/M.1898-1904 tarihli Maârif Salnâmesi'nde Halep mektep idadisinde okutulan dersler ve öğretici kadrosu

\begin{tabular}{|c|c|c|c|c|c|c|}
\hline Yillar & $\begin{array}{c}\text { H.1316- } \\
\text { 1317/ } \\
\text { M.1898- } \\
1899\end{array}$ & $\begin{array}{l}\text { H.1318/ } \\
\text { M.1900 }\end{array}$ & $\begin{array}{l}\text { H.1319/ } \\
\text { M.1901 }\end{array}$ & $\begin{array}{l}\text { H.1321/ } \\
\text { M.1904 }\end{array}$ & Rütbe & Tarih \\
\hline \multicolumn{7}{|l|}{ Memuriyet } \\
\hline Müdür & $\begin{array}{l}\text { Hüsnü } \\
\text { Hazım } \\
\text { Efendi }\end{array}$ & $\begin{array}{l}\text { Hüsnü Hazım } \\
\text { Efendi }\end{array}$ & $\begin{array}{l}\text { Mehmed Faik } \\
\text { Beğ }\end{array}$ & $\begin{array}{l}\text { Mehmet Faik } \\
\text { Efendi }\end{array}$ & - & - \\
\hline Muavin-i Evvel & $\begin{array}{l}\text { Mehmed } \\
\text { Rifat Efendi }\end{array}$ & Nabi Beğ & Şerif Efendi & Şerif Efendi & - & - \\
\hline Muavin Sani & İzzet Beğ & İzzet Beğ & $\begin{array}{l}\text { Mehmet Haşim } \\
\text { Efendi }\end{array}$ & $\begin{array}{l}\text { Mehmet } \\
\text { Haşim Efendi }\end{array}$ & - & - \\
\hline Muavin Salis & $\begin{array}{l}\text { Haşim } \\
\text { Efendi }\end{array}$ & Haşim Efendi & $\begin{array}{l}\text { Musa El Kazım } \\
\text { Efendi }\end{array}$ & $\begin{array}{l}\text { Musa El } \\
\text { Kazım Efendi }\end{array}$ & - & - \\
\hline Katip & $\begin{array}{l}\text { Ahmed } \\
\text { Şükrü } \\
\text { Efendi }\end{array}$ & $\begin{array}{l}\text { Ahmed Şükrü } \\
\text { Efendi }\end{array}$ & $\begin{array}{l}\text { Ahmed Şükrü } \\
\text { Efendi }\end{array}$ & Emin Efendi & - & - \\
\hline Anbar ve depo Memuru & $\begin{array}{l}\text { Hüseyin } \\
\text { Avni Efendi }\end{array}$ & $\begin{array}{l}\text { Hüseyin Avni } \\
\text { Efendi }\end{array}$ & $\begin{array}{l}\text { Hüseyin Avni } \\
\text { Efendi }\end{array}$ & $\begin{array}{l}\text { Hüseyin Avni } \\
\text { Efendi }\end{array}$ & - & - \\
\hline
\end{tabular}

${ }^{3}$ H.1321/M.1904 olan tarih yazar tarafindan 1907 olarak belirtilmiştir. 


\begin{tabular}{|c|c|c|c|c|c|c|}
\hline İmam & $\begin{array}{l}\text { Şeyh Ferid } \\
\text { Efendi }\end{array}$ & $\begin{array}{l}\text { SSeyh Ferid } \\
\text { Efendi }\end{array}$ & $\begin{array}{l}\text { SSeyh Ferid } \\
\text { Efendi }\end{array}$ & $\begin{array}{l}\text { Şeyh Ferid } \\
\text { Efendi }\end{array}$ & - & - \\
\hline Tabib & $\begin{array}{l}\text { Agust } \\
\text { Efendi }\end{array}$ & Agust Efendi & $\begin{array}{l}\text { İsmail Şükrü } \\
\text { Beğ }\end{array}$ & İsmail Efendi & $\begin{array}{l}\text { Binbaş } \\
1\end{array}$ & - \\
\hline $\begin{array}{l}\text { Kitabet Resmiye } \\
\text { Muallimi }\end{array}$ & - & - & $\begin{array}{l}\text { Mahmud } \\
\text { Celaleddin Beğ }\end{array}$ & $\begin{array}{l}\text { Mahmud } \\
\text { Celaleddin } \\
\text { Beğ }\end{array}$ & $\begin{array}{l}\text { Avlı } \\
\text { Saniye }\end{array}$ & $\begin{array}{l}22 \\
\text { Şevval } \\
1313 / 6 \\
\text { Nisan } \\
1896\end{array}$ \\
\hline $\begin{array}{l}\text { Kitabet Resmiye ve } \\
\text { Cebir ve Kavanin ve } \\
\text { Türkçe Muallimi }\end{array}$ & $\begin{array}{l}\text { Hasan } \\
\text { Hazım } \\
\text { Efendi }\end{array}$ & $\begin{array}{l}\text { Hasan Hazım } \\
\text { Efendi }\end{array}$ & $\begin{array}{l}\text { Hasan Hazım } \\
\text { Efendi }\end{array}$ & $\begin{array}{l}\text { Hasan Hazım } \\
\text { Efendi }\end{array}$ & - & - \\
\hline $\begin{array}{l}\text { Cebir, Servet, } \\
\text { Kavaniye, Edebiyat, } \\
\text { Fransizca Muallimi }\end{array}$ & - & - & $\begin{array}{l}\text { Mehmed Faik } \\
\text { Efendi }\end{array}$ & - & - & - \\
\hline Fransızca Mualimi & İzzet Beğ & İzzet Beğ & İzzet Beğ & İzzet Beğ & $\begin{array}{l}\text { Selase } \\
(3)\end{array}$ & $\begin{array}{l}29 \\
\text { Şaban } \\
1314 / 2 \\
\text { Şubat } \\
1897\end{array}$ \\
\hline $\begin{array}{l}\text { Arabi ve Türkçe ve } \\
\text { Ulum-i diniye Muallimi }\end{array}$ & $\begin{array}{l}\text { İsmetullah } \\
\text { Efendi }\end{array}$ & $\begin{array}{l}\text { İsmetullah } \\
\text { Efendi }\end{array}$ & $\begin{array}{l}\text { İsmetullah } \\
\text { Efendi }\end{array}$ & $\begin{array}{l}\text { İsmetullah } \\
\text { Efendi }\end{array}$ & $\begin{array}{l}\text { Musul } \\
\text { e-i } \\
\text { sahn } \\
(2)\end{array}$ & $\begin{array}{l}2 \text { Receb } \\
1302 / \\
17 \\
\text { Nisan } \\
1885\end{array}$ \\
\hline Fransızca Muallimi & $\begin{array}{l}\text { Antuvan } \\
\text { Efendi }\end{array}$ & $\begin{array}{l}\text { Antuvan } \\
\text { Efendi }\end{array}$ & Antuvan Efendi & $\begin{array}{l}\text { Antuvan } \\
\text { Efendi }\end{array}$ & $\begin{array}{l}\text { Rabia } \\
(4)\end{array}$ & - \\
\hline $\begin{array}{l}\text { Kimya, Hikmet, } \\
\text { Hifzüllsıhha } \\
\text { Kozmoğrafya ve } \\
\text { Mevalid Muallimi }\end{array}$ & - & - & Şükrü Efendi & - & - & - \\
\hline $\begin{array}{l}\text { Müsellesat ve } \\
\text { Kozmoğrafya } \\
\text { ve Mevalid ve Kimya } \\
\text { ve Makine } \\
\text { ve Malumat Nafia ve } \\
\text { Hifzülsıhha Muallimi }\end{array}$ & $\begin{array}{l}\text { Mehmed } \\
\text { Rifat Efendi }\end{array}$ & Sabi Beğ & $\begin{array}{l}\text { Abdurrahman } \\
\text { Rahmi Efendi }\end{array}$ & - & - & - \\
\hline $\begin{array}{l}\text { Edebiyat ve Ahlak ve } \\
\text { Hikmet ve Usul Defteri } \\
\text { Muallimi }\end{array}$ & İzzet Beğ & İzzet Beğ & İzzet Beğ & İzzet Beğ & - & - \\
\hline $\begin{array}{l}\text { Tarih ve Coğrafya } \\
\text { Muallimi }\end{array}$ & $\begin{array}{l}\text { Haşim } \\
\text { Efendi }\end{array}$ & Haşim Efendi & Haşim Efendi & Haşim Efendi & $\begin{array}{l}\text { Müder } \\
\text { ris }\end{array}$ & - \\
\hline Arabi Muallimi & Abdi Efendi & Abdi Efendi & Abdi Efendi & Abdi Efendi & - & - \\
\hline $\begin{array}{l}\text { Akaid ve Fıkıh ve Farisi } \\
\text { ve Türkçe Muallimi }\end{array}$ & $\begin{array}{l}\text { Musa el- } \\
\text { Kazım } \\
\text { Efendi }\end{array}$ & $\begin{array}{l}\text { Musa el- } \\
\text { Kazım Efendi }\end{array}$ & $\begin{array}{l}\text { Musa el-Kazım } \\
\text { Efendi }\end{array}$ & $\begin{array}{l}\text { Musa el- } \\
\text { Kazım Efendi }\end{array}$ & - & - \\
\hline $\begin{array}{l}\text { Türkçe Usul Defteri, } \\
\text { Hesab Muallimi }\end{array}$ & - & - & Şükrü Efendi & - & - & - \\
\hline $\begin{array}{l}\text { İnşa ve Kitabet ve } \\
\text { Hesap ve Hendese } \\
\text { Muallimi }\end{array}$ & $\begin{array}{l}\text { Ahmed } \\
\text { Şükrü } \\
\text { Efendi }\end{array}$ & $\begin{array}{l}\text { Ahmed Şükrü } \\
\text { Efendi }\end{array}$ & $\begin{array}{l}\text { Ahmed Şükrü } \\
\text { Efendi }\end{array}$ & $\begin{array}{l}\text { Ahmed Şükrü } \\
\text { Efendi }\end{array}$ & - & - \\
\hline
\end{tabular}




\begin{tabular}{|c|c|c|c|c|c|c|}
\hline Hüsnühat Muallimi & $\begin{array}{l}\text { HasanTahsi } \\
\text { n Efendi }\end{array}$ & $\begin{array}{l}\text { Hasan Tahsin } \\
\text { Efendi }\end{array}$ & $\begin{array}{l}\text { Hasan Tahsin } \\
\text { Efendi }\end{array}$ & $\begin{array}{l}\text { Hasan Tahsin } \\
\text { Efendi }\end{array}$ & - & - \\
\hline Ermenice Muallimi & $\begin{array}{l}\text { Haçadur } \\
\text { Efendi }\end{array}$ & $\begin{array}{l}\text { Haçadur } \\
\text { Efendi }\end{array}$ & Haçadur Efendi & $\begin{array}{l}\text { Haçadur } \\
\text { Efendi }\end{array}$ & - & - \\
\hline Resim Muallimi & $\begin{array}{l}\text { Fethullah } \\
\text { Efendi }\end{array}$ & $\begin{array}{l}\text { Fethullah } \\
\text { Efendi }\end{array}$ & $\begin{array}{l}\text { Fethullah } \\
\text { Efendi }\end{array}$ & $\begin{array}{l}\text { Fethullah } \\
\text { Efendi }\end{array}$ & - & - \\
\hline Mubassir $^{4}$ & - & $\begin{array}{l}\text { Emir Vasfi } \\
\text { Efendi }\end{array}$ & $\begin{array}{l}\text { Emir Vasfi } \\
\text { Efendi }\end{array}$ & Habib Efendi & - & - \\
\hline Mübayaa Memuru ${ }^{5}$ & - & $\begin{array}{l}\text { Mustafa } \\
\text { Efendi }\end{array}$ & Mustafa Efendi & - & - & - \\
\hline $\begin{array}{l}\text { Mevalid ilm-i Servet ve } \\
\text { Fransizca, Ahlak, } \\
\text { Hendese Muallimi }^{6}\end{array}$ & - & - & - & Faik Efendi & - & - \\
\hline $\begin{array}{l}\text { Mekanik, Kozmoğrafya, } \\
\text { Kimya, Hikmet, } \\
\text { Müsellesat ve Hendese } \\
\text { Muallimi }\end{array}$ & - & - & - & Şerif Efendi & - & - \\
\hline $\begin{array}{l}\text { Coğrafya, Tarih ve } \\
\text { Cebir Muallimi }\end{array}$ & - & - & - & $\begin{array}{l}\text { Mehmed } \\
\text { Haşim Efendi }\end{array}$ & - & - \\
\hline $\begin{array}{l}\text { Ziraat dersleri ve } \\
\text { ameliyat ziraiye } \\
\text { Muallimi }\end{array}$ & - & - & - & Hamdi Efendi & - & - \\
\hline $\begin{array}{l}\text { Hesap ilmi, Coğrafya, } \\
\text { İlm-i Eşya, Malumatı } \\
\text { Ziraîyye ve Kavanin } \\
\text { Muallimi }\end{array}$ & & & & $\begin{array}{l}\text { Yervunt } \\
\text { Efendi }\end{array}$ & & \\
\hline $\begin{array}{l}\text { İlmi servetin ziraate } \\
\text { tatbiki ziraat makineleri } \\
\text { ve nebatat-1 ziraiye } \\
\text { Muallimi }\end{array}$ & - & - & - & Şakib Efendi & - & - \\
\hline $\begin{array}{l}\text { Hikmet kimyanın } \\
\text { tatbiki hayvanat ziraiye } \\
\text { ve Hifz'1-Sihha-1 } \\
\text { Hayvanat ve Fen } \\
\text { Muallimi }\end{array}$ & - & - & - & Kemal Efendi & - & - \\
\hline $\begin{array}{l}\text { Coğrafya zirai ve zirai } \\
\text { usul defteri Muallimi }\end{array}$ & - & - & - & Nasuh Efendi & - & - \\
\hline $\begin{array}{l}\text { Mevalid-i Salis } \\
\text { Muallimi }\end{array}$ & - & - & - & $\begin{array}{l}\text { Abdullah } \\
\text { Efendi }\end{array}$ & - & - \\
\hline Hendese Zirai Muallimi & - & - & - & Cevdet Efendi & - & - \\
\hline Ziraat Kesimi Mübaşiri & - & - & - & $\begin{array}{l}\text { İbrahim } \\
\text { Efendi }\end{array}$ & - & - \\
\hline
\end{tabular}

Kaynak: SNMU, 1316, s.1009-1010; 1317, s.1008-1009; 1318, s.1250-1251;1319, s.528-529; 1321, s.455-456

Tablo 1'de görüldüğü üzere idadi ders çeşitliliği ve öğretici kadrosu, eğitim-öğretim faaliyetlerinin sürdürülmesi açısından her türlü imkâna sahiptir. Müdür ve derecesine göre 3 adet müdür yardımcısı bulunmaktadır. Bu lisenin müfredatına bakıldığında; Türkçe'nin yanı sıra Fransızca, Arapça ve Ermenice dillerinin öğretildiğini görülmektedir. Devlete ait tüm eğitim kurumlarında Ermenice dersi Haçadur Efendi adındaki hocalar tarafından verilmektedir. Bu isim Ermeniler tarafindan sıklıkla ad veya soyad olarak kullanılmakta ve genel olarak Haço diye

\footnotetext{
${ }^{4}$ Mubassır ilk kez H.1318/M.1900 tarihli Maârif Salnâmesinde görülmektedir.

${ }^{5}$ Mübaaya memuru ilk kez H.1319/M.1901'de neşredilen Maârif Salnâmesinde geçmektedir.

${ }^{6}$ Buradan itibaren verilen dersler H.1321/M.1904 yılındaki salnâme kayıtlarında bulunmaktadır.
} 
kısaltılmaktadır. Ermeniler yerine Haçolar da denilmektedir. Zaman zaman Haço kullanımı Gâvurlar'a dönüşmüş, Kürtler tarafından da Fılla olarak adlandırılmışlardır (Margosyan, 2017).

İdadinin H.1316-1318/ M.1898-1900 yılları arasında müdürü Hasan Hazım Efendi iken H.1319-1321/M.1901-1904'te bu göreve Mehmet Faik Efendi getirilmiştir. Müdürlük vazifesinde bulunan Hasan Hazım Efendi'nin, kitabet, resmiye, cebir, kavanin, Türkçe derslerine; Mehmet Faik Efendi'nin H.1316-1319/M.1898-1901'de cebir, servet, kavaniye, edebiyat, Fransizca derslerine, H.1321/M.1904'te mevalid, ilm-i servet, Fransizca, ahlak, hendese derslerine girdiği görülür. Muavin-i evvel ise H.1316-1317/M.1898-1899'da Mehmed Rifat Efendi, H.1318/M.1900'de Nabi Bey, H.1319-1321/M.1901-1904'te Şerif Efendi; muavin-i sani H.13161318/M.1898-1900'de İzzet Bey, H.1319-1321/M.1901-1904'te Mehmet Haşim Efendi'dir. Mehmet Rifat, H.1316-1317/M.1898-1899'da Müsellesat, kozmoğrafya, mevalid, kimya, makine, malumat-1 nafia ve hifzülsıhha derslerine girerek daha sonraki y1llarda bu derslere sırasıyla Sabi Bey ve Abdurrahman Rahmi Efendi girmiştir. Şerif Efendi mekanik, kozmoğrafya, kimya, hikmet, müsellesat, hendese derslerinde muallimlik yapmıştır. H.1321/M.1904'te coğrafya, tarih ve cebir derslerine Haşim Efendi girmiştir. Muavin-i Salis H.1316-1318/M.18981900 yıllarında Haşim Efendi, H.1319-1321/M.1901-1904'te Musa el Kazım Efendi'dir. Muavini Sani görevi olan Haşim Efendi'nin bir yıl sonra muavin-i salis vazifesinde üstlendiğini görülmektedir. Akaid, fikıh, Farsça ve Türkçe derslerine giren Musa el-Kazım Efendi H.13191321/M.1901-1904 tarihlerinde okulun idareci kadrosunda da yer almaktadır. Haşim Efendi, tarih ve coğrafya derslerini vermiştir.

H.1316-1319/M.1898-1901 y1llarında kâtip vazifesinde Ahmed Şükrü Efendi, H.1321/M. 1904'te Emin Efendi vardır. Ahmet Efendi H.1316-1321/M.1898-1903 yıllarında inşa, kitabet, hesap, hendese derslerine, H.1319/M.1901'de Türkçe usul defteri ve hesab derslerinin öğreticisidir. H.1319/M.1901 yılında aynı zamanda kimya, hikmet, hıfzüllsıhha, kozmoğrafya, mevalid derslerine de girmiştir. H.1316-1321/M. 1898-1903 zaman aralı̆̆ında ambar ve depo memuru Hüseyin Avni Efendi, imam Şeyh Ferid Efendi, Arabi muallimi Abdi Efendi, Edebiyat, ahlak, hikmet ve usul defteri muallimi İzzet Bey, Fransizca muallimleri Antuvan ve İzzet Efendi, Arabi, Türkçe, Ulum-i diniye muallimi İsmetullah Efendi, hüsnühat muallimi Hasan Hazım Efendi, resim muallimi Fethullah Efendi'dir. Fransızca öğretmeni İzzet Beye 29 Şaban 1314 (2 Şubat 1897)'de selase (3) rütbesi, Antuvan Efendiye rabia (4) rütbesi, Arapça ve Türkçe öğretmeni İsmetullah Efendiye 2 Receb 1302/17 Nisan 1885'te Musule-i sahn (2) rütbesi verilmiştir. H.1316-1318/M.1898-1900 yıllarında tabib olan Agust (Oğust) Efendi'nin rütbesi binbaş1 olup, bu vazifeyi H.1319-1321/M.1901-1904 yıllarında İsmail Şükrü Bey ifa etmiştir. H.1319-1321/M.1901-1904 yıllarında kitabet resmiye dersine Mahmud Celaleddin Bey girmiştir. Mahmud Beyin 22 Şevval 1313/Nisan 1896 tarihinde verilmiş olan avlı saniye rütbesi bulunmaktadır. H.1318-1319/M.1900-1901 tarihlerinde idadide Mubassır görevinde Emir Vasfi Efendi, 1903 'te Habib Efendi; mübayaa memuru vazifesinde ise Mustafa Efendi vardır. 1904'te hesap ilmi, coğrafya, ilm-i eşya, malumatı zirâiyye ve kavanin muallimi ise Yervunt Efendi'dir.

H.1321/M.1904 y1lına gelindiğinde daha önceki senelerde programda bulunmayan, ziraat, ziraat makineleri, nebatat, hayvanat, ziraat mübaşiri, kimyanın tatbiki gibi uygulamaya ve meslek eğitimine yönelik derslere yer verilmiştir.

5. sinıftan itibaren verilen Malumat-1 Fenniye dersi genel itibariyle ziraat, hayvanc1lık, iletişim araçları, bitkiler gibi konuları içermektedir. 3. yıldan itibaren verilen Hifz'1-Sıhha dersinde ise hava ve sağlığa etki eden unsurlar, bitkisel ve hayvansal gıdalar, bulaşıcı hastalıklar, sağlıkta dikkat edilmesi gereken faktörler hakkında bilgi verilmektedir. 3-4 ve 5. sinıfta yer alan Coğrafya dersini içeren İlm-i Eşya dersinde yer kürenin katmanları, hava, su, ateş ve insan bedenine dair konular, dokuma ürünleri, bitki tohumları, sanayi ve ziraata dair bilgiler, meslekler ve sanayi hakkında kademeli bir eğitim verilir.

6. sinıfta Edebiyat ve Kitabet-i Resmiye bazen Edebiyat ve Ahlâk olarak verilen derste öğrencilere üslûp, söz sanatları, günlük ve resmi yazışmaların ayrımı ve yazımda dikkat edilmesi 
gereken kurallar belirtilmekte, Ahlâk dersinde insan ilişkilerinde dikkat edilmesi gereken kurallar öğretilmektedir. Bu derste yazışma, dilekçe rapor örnekleri verilmekte 7. sınıfta Osmanlı edebiyat tarihi hakkında bilgi verilip 8. sınıfta edebi makaleler yazdırılmaktadır. $\mathrm{Bu}$ eğitimin kademeli olarak sarmal bir program çerçevesinde özelden genele, yakından uzağa ilkesi temel alınarak öğretildiğinin göstergesidir. Bu derslerde kısa ahlak hikâyeleri okunarak öğrencilerin yaşama dönük çıkarımlar yapması sağlanmıştır. 7. sınıf programında yer alan Kavanin dersi çocuklara mahkemeler, görevleri ve kimlerden oluştuğu hakkında bilgi vermesi bakımından hak ve sorumluluklarını bilen etkin yurttaş yetiştirmeye hizmet eden bir derstir. 7. sınıfta verilen İlm-i Servet dersinde, iktisadın tanımı, çeşitleri, sınıflandırılması, üretim vasıtaları gibi başlıca konular ele alınmakta ögrencilere alım-satım, ithalat-ihracat, tüketim konularında bilgi verilmektedir. 7. sınıfta verilmeye başlanan İlm-i Mevalid dersinde, canlı-cansız varlıkların sınıflandırılmaları, hayvanlar ile bitkiler arasındaki farklar, bitkilerin yapısı, çoğalması, madenler ve jeolojik kayaçlar, dünyanın jeolojik yapısı, sıcaklık merkezi gibi konular anlatılmaktadır (Turan ve Ulusoy, 2010; Yaslıçimen, 2018).

Öğrencilerin iletişim becerilerini geliştirme açısından Malumat-1 fenniye, Kitabet, Türkçe, Edebiyat, Hüsnühat dersleri önemlidir. Malumat-1 Nafia ile öğrencilere gündelik hayatlarında yararlı olacak bilim ve teknik ile ilgili bilgiler verilir. Hüsnühat dersi ile öğrencilere güzel yazı yazma, okuduğunu iyi anlama, aynı zamanda dinleme becerilerinin gelişmesi sağlanır.

Tablo 2. H.1316-1321/M.1898-1904 tarihli Maârif Salnâmelerine göre Halep mektep idadisinin öğrenci ve hademe sayısı

\begin{tabular}{|c|c|c|c|c|c|c|c|c|c|}
\hline & \multicolumn{2}{|c|}{ Yekûn (Toplam) } & \multicolumn{2}{|c|}{ Nevari (Gündüzlü) } & \multicolumn{5}{|c|}{ Leyli (Geceli) } \\
\hline & \multirow{2}{*}{$\begin{array}{c}\text { Gayri } \\
\text { müslim }\end{array}$} & \multirow[t]{2}{*}{ Müslim } & \multirow[t]{2}{*}{ Gayrimüslim } & \multirow[t]{2}{*}{ Müslim } & \multicolumn{2}{|c|}{ Ücretsiz } & \multicolumn{2}{|c|}{ Ücretli } & \multirow{2}{*}{$\begin{array}{l}\mathrm{Ha} \\
\mathrm{de} \\
\mathrm{me}\end{array}$} \\
\hline & & & & & G.müslim & Müslim & G.müslim & Müslim & \\
\hline $\begin{array}{l}1313-1314 \\
(1316)^{7}\end{array}$ & 7 & 114 & 6 & 59 & - & 19 & - & 36 & - \\
\hline $\begin{array}{l}1314-1315 \\
(1317)\end{array}$ & 8 & 107 & 7 & 63 & 1 & 18 & - & 26 & 9 \\
\hline $\begin{array}{l}1315-1316 \\
(1318)\end{array}$ & 11 & 141 & 10 & 98 & 1 & 20 & - & 23 & 8 \\
\hline $\begin{array}{l}1316-1317 \\
(1319)\end{array}$ & 11 & 197 & 10 & 140 & 1 & 21 & - & 36 & 8 \\
\hline $\begin{array}{l}1318-1319 \\
(1321)\end{array}$ & 11 & 233 & 10 & 181 & 1 & 16 & - & 36 & 9 \\
\hline
\end{tabular}

Kaynak: SNMU, 1316, s.1009-1010; 1317, s.1008-1009; 1318, s.1250-1251;1319, s.528-529; 1321, s.455-456

H.1316/M.1898 tarihli Maârif Salnâmesi verileri ışığında devlete ait Halep Mektep İdadisin'de 1313-1314 sene tedrisimi zarfında 114 Müslim öğrenci öğrenim görmekteyken gündüzlü 6, geceli (yatıl1) 1 olmak üzere toplam 7 Gayrimüslim öğrenci eğitim görmüştür (SNMU, 1316, s.1009). H.1317/M.1899 tarihli Maârif Salnâmesi verilerine göre, 1314-1315 öğretim yılında Halep Mektep İdadisinde 107 Müslim öğrenci kayıtlı iken yatılı ve ücretsiz eğitim gören 1, gündüz eğitim gören 7 toplam 8 Gayrimüslim öğrenci bulunmaktadır (SNMU, 1317, s.1109). 1315-1316 ders y1lında ise Halep Mektep İdadisine devam eden 141 Müslim öğrenci varken, gündüzlü 10, yatılı ve ücretsiz eğitim gören 1 olmak üzere toplam 11 Gayrimüslim öğrenci vardır (SNMU, 1318, s.1251). H.1316-1317/M.1898-1899 senesinde ise 197 Müslim

${ }^{7}$ H.1316/M.1898 numaralı Maârif Salnâmesi olup 1313-1314 eğitim-öğretim yılının verilerini vermesinin nedeni Osmanlı salnâmeleri içeriği açısından yayınlandığı tarihten bir yıl öncesine ait devletin ve vilâyetlerin tarihi, coğrafyası, nüfusu, idari, askeri, hukuki teşkilatları ve ekonomik durumu, eğitim yapısı hakkında bilgi ihtiva eden vesikalardır (Pakalın, 1983; Palalı, 2010). 
öğrenci mevcutken, gündüzlü 10 , yatılı ve ücretsiz eğitim gören 1 olmak üzere toplam 11 Gayrimüslim mevcuttur (SNMU, 1319, s.529). H.1318-1319/M.1900-1901 y1lında 233 Müslim öğrenci öğrenim görmekte iken gündüzlü 10, yatılı ve ücretsiz eğitim gören 1 olmak üzere toplam 11 Gayrimüslim eğitim faaliyetlerinden yararlanmıştır (SNMU, 1321, s.456-457). İdadi de H.1318-1319/M.1900-1901 yıllarında 8, H.1317/M.1899 ve H.1321/M.1904 yıllarında 9 hademe görev yapmıştır. İlk salnâme olan 1898'da hademe sayısı belirtilmemiştir. Osmanlılık fikrini aşılamak için Maârif-i Umumiye Nizamnamesi doğrultusunda her ne kadar eğitim kurumlarına önemli bir misyon yüklenerek idadilerde Müslüman ve Gayrimüslim öğrencilerin bir arada okuması kararlaştııılsa da Gayrimüslimler için azınlık ve yabancı okulların varlığı, devletin bu politikasına sıcak bakmamalarına neden olmuştur.

\subsection{Medreseler}

Medreseler Türklerin yerleşik hayata geçmeleri ile birlikte İslam dünyasında ortaya çıkan eğitim kurumlarıdır. Medreselerde ilköğretim üstü eğitim verilmiştir. Genellikle tek katlı, bir avlu etrafında dershane ve öğrenci odalarından oluşan bu kurumların faaliyetlerini sürdürmesinde çevresinde bulunan vakıf kütüphaneleri önemli rol oynamıştır (Sami, 1998; İpşirli, 2003). Gazneliler ile başlayan bu kurumlar Selçuklu döneminde gelişerek Nizamiye medreseleri kendinden sonraki dönemlerde inşa edilen medreselere model olmuştur. Selçuklu medreselerinin takipçisi konumunda olan Osmanlı medreseleri Fatih ve Kanuni döneminde yaptırılan Sahn-1 Seman ve Süleymaniye medreseleri olarak ikiye ayrılmıştır (Uzunçarş111, 2014). Halep merkez kazasında yer alan medreseler tabloda gösterildiği gibidir:

Tablo 3. H.1317-1321/M.1899-1904 Halep'te bulunan medreseler hakkında bilgiler

\begin{tabular}{|c|c|c|c|c|c|c|}
\hline \multirow{2}{*}{$\begin{array}{l}\text { Medresenin } \\
\text { İsmi }\end{array}$} & \multirow{2}{*}{$\begin{array}{l}\text { Bulunduğu } \\
\text { Mevki }\end{array}$} & \multirow[t]{2}{*}{ Müderris } & \multicolumn{3}{|c|}{ Öğrenci Sayısı } & \multirow{2}{*}{$\begin{array}{l}\text { Medresenin } \\
\text { Kurucusu }\end{array}$} \\
\hline & & & $\begin{array}{l}1317- \\
1899\end{array}$ & $\begin{array}{l}1318 / 1319 \\
1900 / 1903\end{array}$ & $\begin{array}{l}1321- \\
1904\end{array}$ & \\
\hline $\begin{array}{l}\text { Osmaniye } \\
\text { Medresesi }\end{array}$ & $\begin{array}{l}\text { Karkara } \\
\text { Mahalisi }\end{array}$ & $\begin{array}{l}\text { Şeyh Hüseyin ve Selim } \\
\text { ve Mehmed Efendiler }\end{array}$ & 168 & 172 & 180 & Osman Paşa \\
\hline $\begin{array}{l}\text { Karnahiye } \\
\text { Medresesi }\end{array}$ & $\begin{array}{l}\text { Karakara } \\
\text { Mahalisi }\end{array}$ & $\begin{array}{l}\text { Mehmed Cizmani ve } \\
\text { Şeyh Beşir Paşa }\end{array}$ & 35 & 30 & 40 & Na'malum \\
\hline $\begin{array}{l}\text { İsmailiye } \\
\text { Medresesi }\end{array}$ & $\begin{array}{l}\text { Karakara } \\
\text { Mahalisi }\end{array}$ & Şeyh Abdi Efendi & 30 & 22 & 25 & İsmail Paşa \\
\hline $\begin{array}{l}\text { Seyfiye } \\
\text { Medresesi }\end{array}$ & $\begin{array}{l}\text { Karakara } \\
\text { Mahalisi }\end{array}$ & Şeyh Mehmed Nesani & $01^{8}$ & 11 & 15 & $\begin{array}{l}\text { Seyyafzade } \\
\text { İbrahim Ağa }\end{array}$ \\
\hline $\begin{array}{l}\text { Şabaniye } \\
\text { Medresesi }\end{array}$ & $\begin{array}{l}\text { Karakara } \\
\text { Mahalisi }\end{array}$ & $\begin{array}{l}\text { Şeyh Mehmed Zerne ve } \\
\text { Şeyh Vedihi Efendiler }\end{array}$ & 80 & 83 & 85 & Said Paşa \\
\hline $\begin{array}{l}\text { Mansuriye } \\
\text { Medresesi }\end{array}$ & $\begin{array}{l}\text { Karakara } \\
\text { Mahalisi }\end{array}$ & $\begin{array}{l}\text { Şeyh Mehmed Nesani } \\
\text { ve Şeyh Ahmed Sadik } \\
\text { Efendiler }\end{array}$ & - & - & 5 & $\begin{array}{l}\text { Şeyh Mehmed } \\
\text { Efendi } \\
\text { Mansure }\end{array}$ \\
\hline $\begin{array}{l}\text { Asruniye } \\
\text { Medresesi }\end{array}$ & $\begin{array}{l}\text { Karakara } \\
\text { Mahalisi }\end{array}$ & $\begin{array}{l}\text { Kura-izade Rüşdi } \\
\text { Efendi }\end{array}$ & 13 & 13 & 10 & $\begin{array}{l}\text { Şeyh } \\
\text { Hüsameddin } \\
\text { Efendi }\end{array}$ \\
\hline Bahaiye & $\begin{array}{l}\text { Suyukta Hanım } \\
\text { Mahali }\end{array}$ & $\begin{array}{l}\text { Şeyh Emir Martini ve } \\
\text { Şeyh Ahmedzade } \\
\text { Efendiler }\end{array}$ & 16 & 18 & 20 & $\begin{array}{l}\text { Bahaeddin } \\
\text { Efendi }\end{array}$ \\
\hline Cehar tekye & $\begin{array}{l}\text { Suyukta Hanım } \\
\text { Mahali }\end{array}$ & $\begin{array}{l}\text { Şeyh Abdurrahman } \\
\text { Efendi }\end{array}$ & 4 & 6 & 8 & $\begin{array}{l}\text { Şeyh Esad } \\
\text { Efendi }\end{array}$ \\
\hline Ahmediye & $\begin{array}{l}\text { Culum-1 Kübra } \\
\text { Mahali }\end{array}$ & $\begin{array}{l}\text { Şeyh Hüseyin ve } \\
\text { Ahmed ve Mehmed ve } \\
\text { Ahmed Efendiler }\end{array}$ & 22 & 20 & 21 & $\begin{array}{l}\text { Tahzade } \\
\text { Ahmed Efendi }\end{array}$ \\
\hline
\end{tabular}

\footnotetext{
${ }^{8}$ Bu sayı 10 da olabilir. Katip salnâme kayıtları tutarken yanlış yazmış olma ihtimali vardır. Çünkü 1 öğrencisi olsa başına sıfır rakamı koyması gerekmezdi.
} 


\begin{tabular}{|c|c|c|c|c|c|c|}
\hline Hulviye & $\begin{array}{l}\text { Ceb Esadah } \\
\text { Mahali }\end{array}$ & Şeyh Mehmed Efendi & 28 & 24 & 25 & $\begin{array}{l}\text { Şeyh Mustafa } \\
\text { Efendi }\end{array}$ \\
\hline Caferiye & $\begin{array}{l}\text { Ceb Esadah } \\
\text { Mahali }\end{array}$ & Şeyh Hüseyin Efendi & 6 & 8 & 10 & Eşref Efendi \\
\hline Hacı Musa & $\begin{array}{l}\text { Suykate Ali } \\
\text { Mahali }\end{array}$ & $\begin{array}{l}\text { Şeyh Ahmed Efendi } \\
\text { Rizaz }\end{array}$ & 8 & 15 & 12 & $\begin{array}{l}\text { Ahmed Ata } \\
\text { Efendi }\end{array}$ \\
\hline Seyidiye & Beyaza Mahali & $\begin{array}{l}\text { Ahmed ve Mehmed ve } \\
\text { Abdülkerim Efendiler } \\
\text { ile Sairleri }\end{array}$ & 20 & 8 & 9 & $\begin{array}{l}\text { Emeviyeden } \\
\text { Sultan } \\
\text { Abdülmelik }\end{array}$ \\
\hline Eşrefiye & $\begin{array}{l}\text { Suyukta Hanım } \\
\text { Mahali }\end{array}$ & Şeyh Abdi Efendi & 15 & 7 & 10 & Ebul Hasan \\
\hline $\begin{array}{l}\text { Muytab Ahmed } \\
\text { Paşa }\end{array}$ & $\begin{array}{l}\text { Suyukta Hanım } \\
\text { Mahali }\end{array}$ & $\begin{array}{l}\text { Şeyh Ahmed Efendi } \\
\text { Rizaz }\end{array}$ & 2 & 10 & 12 & Mehmed Paşa \\
\hline Cami Kebir & $\begin{array}{l}\text { Suyukta Hanım } \\
\text { Mahali }\end{array}$ & $\begin{array}{l}\text { Şeyh Abdi Efendi } \\
\text { Maafi }\end{array}$ & 1 & 220 & 200 & Hüsrev Paşa \\
\hline $\begin{array}{l}\text { Cami Kebir ben- } \\
\text { i aşli Medresesi }\end{array}$ & $\begin{array}{l}\text { Suyukta Hanım } \\
\text { Mahali }\end{array}$ & Müderris yoktur & - & 10 & 12 & $\begin{array}{l}\text { Şehabettin } \\
\text { Efendi }\end{array}$ \\
\hline $\begin{array}{l}\text { Adliye } \\
\text { Medresesi }\end{array}$ & Sefahe Mahali & Osman Efendi & 7 & 3 & - & $\begin{array}{l}\text { Ali Elnacar } \\
\text { Efendi }\end{array}$ \\
\hline $\begin{array}{l}\text { Hüsreviye } \\
\text { Medresesi }\end{array}$ & Sefahe Mahali & Fahreddin Efendi & 4 & 2 & 4 & Na'malum \\
\hline $\begin{array}{l}\text { Sultaniye } \\
\text { Medresesi }\end{array}$ & Sefahe Mahali & Osman Paşa & 4 & - & 4 & Sonkarlı Efendi \\
\hline
\end{tabular}

Kaynak: SNMU 1317, s.1114-1115; 1318, s.1258-1259; 1319, s.540-541; 1321, s.462

Tablo 3 incelendiğinde Halep merkez sancağında Osmaniye, Karnahiye, İsmailiye, Seyfiye, Şabaniye, Mansuriye, Asruniye, Bahaiye, Cehar tekye, Ahmediye, Hulviye, Caferiye, Hacı Musa, Seyidiye, Eşrefiye, Muytab Ahmed Paşa, Cami Kebir, Cami Kebir ben-i aşli, Adliye, Sultaniye ve Hüsreviye Medresesi olmak üzere toplam 21 medrese bulunmaktadır. Medreseler ağırlıklı olarak Karakara, Sefahe ve Suyukta Hanım mevkilerinde olmakla birlikte Beyaza, Ceb Esedah, Culum-i Kübra mevkilerinde inşa edilmiştir. Karnahiye ve Hüsreviye medreselerinin kurucuları belirtilmemiş̧ir. Seyidiye medresesinin kurucusunun Emeviye'den Sultan Abdülmelik olduğu ifade edilmiştir. 1899 yılında 1 öğrencisi olan Camii Kebir ben-i aşli medresesinin o yı1 müderrisi olmadığı bilgisi mevcuttur. 1899-1903 yılları arasında Mansuriye medresesinin, 1899 yılında Camii Kebir ben-i işla medresesinin, 1904 yılında Adliye medresesinin, 1900-1903 yılları arasında Sultaniye medresesinin öğrencisi bulunmamaktadır. Osmaniye medresesinde 1899 yılında 168; 1900-1903 yılları arasında 172; 1904 yılında 180 öğrenci öğrenim görmüştür. 1899 yılında bir öğrencisi olan Camii Kebir medresesinin 1900-1903 yılları arasında 220; 1904 yılında 200 öğrencisi mevcut olarak en fazla öğrencisi olan medrese olmuştur. En az öğrenciye sahip medreseler ise Mansuriye, Cehar tekye, Sultaniye, Hüsreviye, Adliye, Camii Kebir ben-i işla, Eşrefiye, Muytap Ahmed Paşa medreseleridir. 4 müderris ile en fazla müderrise sahip medrese ise Ahmediye medresesidir. 
Tablo 4. H.1317-1321/M.1899-1904 yılları arasında müderrisi ve kurucusu değișen medreseler

\begin{tabular}{|c|c|c|c|c|}
\hline $\begin{array}{l}\text { Medresenin } \\
\text { İsmi }\end{array}$ & $\begin{array}{l}\text { H.1317/ } \\
\text { M.1899 } \\
\text { Müderrisi } \\
\end{array}$ & $\begin{array}{l}\text { H.1318-1321/ } \\
\text { M.1900-1904 } \\
\text { Müderrisi }\end{array}$ & $\begin{array}{l}\text { H.1317/ } \\
\text { M.1899 } \\
\text { Kurucusu } \\
\end{array}$ & $\begin{array}{l}\text { H.1318-1321/ } \\
\text { M.1900-1904 } \\
\text { Kurucusu } \\
\end{array}$ \\
\hline Caferiye & $\begin{array}{l}\text { Şeyh Hüseyin } \\
\text { Efendi }\end{array}$ & Şeyh Hüseyin Efendi & Eşref Efendi & $\begin{array}{l}\text { Evkaf } \\
\text { Hümayun }\end{array}$ \\
\hline Hac1 Musa & $\begin{array}{l}\text { Şeyh Ahmed Efendi } \\
\text { Rizaz }\end{array}$ & $\begin{array}{l}\text { Abdülkadir ve Haşim } \\
\text { Efendiler }\end{array}$ & Ahmed Ata Efendi & $\begin{array}{ll}\text { Haci } & \text { Musa } \\
\text { Efendi } & \\
\end{array}$ \\
\hline Seydiye & $\begin{array}{l}\text { Ahmed ve Mehmed } \\
\text { ve Abdülkerim } \\
\text { Efendiler ile Sairleri }\end{array}$ & $\begin{array}{l}\text { Şeyh Mehmed Rizaz } \\
\text { ve Şeyh Cizmani } \\
\text { Efendiler }\end{array}$ & $\begin{array}{l}\text { Emeviye'den Sultan } \\
\text { Abdülmelik }\end{array}$ & Meçhul \\
\hline Eşrefiye & Şeyh Abdi Efendi & $\begin{array}{lr}\text { Müderrisi } & \text { olmayıp } \\
\text { medresede } & \text { talebe } \\
\text { zikir okurlar } & \\
\end{array}$ & Ebul Hasan & Eşref Efendi \\
\hline $\begin{array}{l}\text { Muytab Ahmed } \\
\text { Paşa }\end{array}$ & $\begin{array}{l}\text { Şeyh Ahmed Efendi } \\
\text { Rizaz }\end{array}$ & $\begin{array}{l}\text { Şeyh Ahmed Efendi } \\
\text { Rızaz }\end{array}$ & Mehmed Paşa & $\begin{array}{l}\text { Ahmed Ata } \\
\text { Efendi }\end{array}$ \\
\hline Cami Kebir & $\begin{array}{l}\text { Şeyh Abdi Efendi } \\
\text { Maafi }\end{array}$ & $\begin{array}{l}\text { Ahmed ve Mehmed } \\
\text { ve Abdülkerim } \\
\text { Efendiler ile Saire }\end{array}$ & Hüsrev Paşa & $\begin{array}{l}\text { Emeviye'den } \\
\text { Sultan } \\
\text { Abdülmelik } \\
\end{array}$ \\
\hline $\begin{array}{lr}\text { Cami } & \text { Kebir } \\
\text { ben-i } & \text { aşli } \\
\text { Medresesi } & \\
\end{array}$ & Müderris yoktur & Şeyh Abdi Efendi & Şehabettin Efendi & Ebul Hasan \\
\hline $\begin{array}{l}\text { Adliye } \\
\text { Medresesi }\end{array}$ & Osman Efendi & Şeyh Ahmed Efendi & Ali Elnacar Efendi & Mehmed Paşa \\
\hline $\begin{array}{l}\text { Hüsreviye } \\
\text { Medresesi }\end{array}$ & Fahreddin Efendi & Şeyh Abdi Efendi & Na'malum & Hüsrev Paşa \\
\hline
\end{tabular}

Kaynak: SNMU 1317, s.1114-1115; 1318, s.1258-1259; 1319, s.540-541; 1321, s.462

Tablo 4 incelendiğinde Hacı Musa, Seydiye, Eşrefiye, Muytab Ahmed Paşa, Cami Kebir, Cami Kebir ben-i aşli, Adliye ve Hüsreviye medreselerinin 1899 y1lı ile 1900-1904 yılları arasındaki müderris ve kurucusu isimleri değişiklik göstermektedir. Caferiye medresesinin müderrisi yıllara göre değişiklik göstermemiş olup sadece 1899 yılında kurucusu Eşref Efendi iken 1900-1904 arası Evkaf Hümayun olarak zikredilmiştir. 1899 yılında Seydiye medresesinin kurucusunun Emeviye'den Sultan Abdülmelik olduğu ifade edilirken 1900-1904 yılları arasında meçhul olarak zikredilmiştir. Aynı şekilde Hüsreviye medresesinin 1899'da kurucusu Na'malum (belirsiz) iken 1900-1904 arasında Hüsrev Paşa olduğu belirtilmektedir. Camii Kebir medresesinin 1899'da kurucusu Hüsrev Paşa olarak geçerken 1900-1904 arasında kurucusunun Emeviye'den Sultan Abdülmelik olduğu ifade edilmiştir. Müderris isimlerinin değişkenlik göstermesinin vefat, atama, tayin gibi nedenlerle olası olduğunu söylemek mümkündür. Buna karşın medreselerin kurucu isimlerinin y1llara göre değişiklik göstermesi ise istisnai bir durumdur. Illk sene meçhul olarak zikredilip daha sonraki yıllarda medresenin kurucu isimlerinin zikredilmesini yapılan araştırmalar neticesinde kurucusunun kim olduğunun öğrenildiği ile açıklanabilir. 1899'da kurucu ismi belirtilirken sonraki yıllarda meçhul olduğu bilgisi olan medreselerde kurucunun yerine vasi birakmadan vefat etmesi sonucu belirsizlik olduğu yorumu yapılabilir. Buna göre 1899 ve 1900-1904 yılları arasında isimlerin farklılık göstermesi ise asıl kurucunun vefat edip yerine vasi yoluyla veyahut medrese ile alakadar olan başka birinin olmasından kaynaklandığı söylenilebilir.

\subsection{Kütüphaneler}

Osmanlı klasik dönem eğitim-öğretim kurumları arasında önemli bir yeri bulunan kütüphaneler çoğunlukla özel araştırmalar yapılması amacıyla kurulan vakıf eserlerdir. Kütüphanelerde eğitim-öğretim faaliyetlerinden sorumlu olan kişilere Hafız-1 kütüp denilmekle 
birlikte bu kişilerin liyakâtli insanlardan seçilmesine ehemmiyet verilmiştir (Baltac1, 2002; Krenkow, 1993). Halep merkez kazasında bulunan kütüphaneler şunlardır:

Tablo 5. H.1316-1321/M.1898-1904 Halep’te bulunan kütüphaneler hakkında bilgiler

\begin{tabular}{|c|c|c|c|c|}
\hline Kütüphanenin Adı & Bulunduğu Mevki & Kurucusu & $\begin{array}{c}\text { Kitap } \\
\text { adet }\end{array}$ & $\begin{array}{c}\text { Kuruluş } \\
\text { Tarihi }\end{array}$ \\
\hline Ahmediye & Culum-i Kübra & Tahzade Ahmed Efendi & 1.467 & 1165 \\
\hline Camii Kebir & Suyukta Hanım & Hacı Mahmud Efendi & 807 & 1305 \\
\hline Mevleviye & Babülcenin & Meçhuldur & 228 & Meçhul \\
\hline Bahaiye & Suykate Ali & Bahaeddin Efendi & 70 & 1262 \\
\hline Osmaniye & Karakara & Osman Paşa & 1.242 & 1142 \\
\hline Karnahiye & Karakara & Meçhul & 21 & Meçhul \\
\hline İsmailiye & Karakara & İsmail Paşa & 51 & 1255 \\
\hline Vakfiye $^{9}$ & Şuur-i Kadimde & Şeyh Yemeni & 120 & 1300 \\
\hline Şeyh Abdurrahman & Darbiyede & Şeyh Abdurrahman Efendi & 50 & 1303 \\
\hline Nakibiye & Nakib Camii Şerifi & Hacı Sadık Efendi & 800 & 1280 \\
\hline Aşağı Suriyeli & Nuraldin & Kör Hasan Ağa & 350 & Meçhul \\
\hline Mevlevihane & Tekye & $\begin{array}{l}\text { Mevlevi Seyid Hamid Subuhi } \\
\text { Efendi }\end{array}$ & 244 & 1314 \\
\hline Şihabiye & Şihabiye & Hacı Bekir Şahab & 77 & Meçhul \\
\hline Kayalızade & Kayalı & Kayalızade & 350 & Kadimdir \\
\hline Martinizade & Martini & Martinizade & 350 & Kadimdir \\
\hline Müftü Efendi & Fetvahanede & Ayaşzade & 600 & Kadimdir \\
\hline $\mathrm{Ke}(\mathrm{a})$ ndizade & $\mathrm{Ke}(\mathrm{a})$ ndizade & Yusuf Efendi & 1.200 & Kadimdir \\
\hline
\end{tabular}

Kaynak: SNMU 1316, s.1018-1019; 1317, s. 1132-1133; 1318, s. 1280-1281; 1319, s. 548-49; 1321, s. 478

Halep merkez sancağında Ahmediye, Camii Kebir, Mevleviye, Bahaiye, Osmaniye, Karnahiye, İsmailiye, Vakfiye, Şeyh Abdurrahman, Nakibiye, Aşağı Suriyeli, Mevlevihane, Şihabiye, Kayalızade, Martinizade, Müftü Efendi ve Ke(a)ndizade olmak üzere toplam 16 kütüphane bulunmaktadır. Osmaniye, Karnahiye, İsmailiye kütüphaneleri Karakara; Kayalı, Martini, Kendizade kütüphaneleri isimleri ile aynı adı taşıyan mevkilerde yer almakta olup kurucularının isimleri de aynıdır. Mevleviye ve Karnahiye kütüphanelerinin kurucuları ise meçhul olarak belirtilmiştir. Mevleviye, Karnahiye, Aşağ Suriyeli, Şihabiye kütüphanelerinin kuruluş tarihleri belli olmamakla birlikte Kayalızade, Martinizade, Müftü Efendi ve Ke(a)ndizade kütüphanelerinin kuruluşunun eskilere dayandığı bilgisi mevcuttur. İlk kurulan kütüphane 1142 ile Osmaniye olup diğer kütüphaneler sirasiyla Ahmediye 1165; İsmailiye 1255; Bahaiye 1262; Nakibiye 1280; Vakfiye 1300; Şeyh Abdurrahman 1303; Camii Kebir 1305'te açılmıştır. Faaliyete en son geçen kütüphane ise 1314 yılı ile Mevlevihane kütüphanesidir. En fazla kitap bulunan kütüphaneler Ahmediye (1.467); Osmaniye (1.242); Kendizade (1.200); Camii Kebir (807); Nakibiye (800) iken en az kitap bulunan kütüphaneler ise Karnahiye (21); Şey Abdurrahman (50); İsmailiye (51); Bahaiye (70); Şihabiye (77)'dir. Aşağ1 Suriyeli, Kayalızade ve Martinizade kütüphanelerinde ise 350 kitap bulunmaktadır. 16 kütüphane bünyesinde toplam 8.027 kitap mevcuttur.

\subsection{Gazete ve Matbaalar}

Halep'te Arapça ve Türkçe yayın yapan "Ferat" adında bir adet gazete, biri devlete ait Vilâyet, diğer ikisi Marûni ve Davudiye matbaası olmak üzere 3 adet matbaa bulunmaktadır (SNMU, 1316, s. 1020; 1317, s. 1124-1125; 1318, s. 1272-1273).

\footnotetext{
${ }^{9}$ Vakfiye kütüphanesinden itibaren bulunan kütüphaneler H.1317/M.1899 tarihli Maârif Salnâmesi ve sonraki salnâmelerde yer almaktadır.
} 
Tablo 6. Maârif salnâmelerine göre Halep Sancağı'nda bulunan matbaalar

\begin{tabular}{|c|c|c|c|c|c|}
\hline $\begin{array}{l}\text { Matbaanın } \\
\text { İsmi }\end{array}$ & $\begin{array}{l}\text { Bulunduğu } \\
\text { Mevki }\end{array}$ & $\begin{array}{l}\text { Sahip } \\
\text { İmtiyazı }\end{array}$ & Nüa & $\begin{array}{l}\text { Hangi } \\
\text { lisanlarda } \\
\text { eser tabiî } \\
\text { ettikleri }\end{array}$ & Kuruluş Tarihi \\
\hline $\begin{array}{l}\text { Vilâyet } \\
\text { Matbaası }\end{array}$ & $\begin{array}{l}\text { Hükümet } \\
\text { Konağında }\end{array}$ & Resmi & $\begin{array}{l}\text { Taş ve Harufat } \\
\text { (Resim } \\
\text { basılamaz) }\end{array}$ & $\begin{array}{l}\text { Türkçe ve } \\
\text { Arapça }\end{array}$ & $\begin{array}{l}\text { H.1284/M.1867- } \\
1868\end{array}$ \\
\hline $\begin{array}{l}\text { Maruni } \\
\text { Matbaası }\end{array}$ & $\begin{array}{l}\text { Salibe } \\
\text { Mahallesinde }\end{array}$ & $\begin{array}{l}\text { Haceneum } \\
\text { ibn-i İlyas } \\
\text { Hekim } \\
\text { Efendi }\end{array}$ & $\begin{array}{l}\text { Taş ve Harufat } \\
\text { (Resim } \\
\text { basılamaz) }\end{array}$ & Türkçe & $\begin{array}{l}\text { H.1246/M.1830- } \\
1831\end{array}$ \\
\hline $\begin{array}{l}\text { Davudiye } \\
\text { Matbaası }\end{array}$ & $\begin{array}{l}\text { Bahsita } \\
\text { Mahallesinde }\end{array}$ & $\begin{array}{l}\text { Haham } \\
\text { Şabani }\end{array}$ & $\begin{array}{l}\text { Taş ve Harufat } \\
\text { (Resim } \\
\text { basılamaz) }\end{array}$ & İbranice & $\begin{array}{l}\text { H.1311/M.1893- } \\
1894\end{array}$ \\
\hline
\end{tabular}

Kaynak: SNMU, 1316, s.1020-1021; 1317, s.1124-1125; 1318, s.1272-1273; 1319, s.548-549; 1321, s.469

Tablo'da yer alan bilgilere göre Hükümet konağı mevkisinde bulunan Vilâyet matbaası H.1284/M.1867-68 yılında faaliyete başlamış olup Türkçe ve Arapça dillerinde eser neşretmiştir. İlyas Hekim adına imtiyazı bulunan Maruni matbaası H.1246/M.1830-31'de Salibe mahallesinde kurulmuş olup Türkçe eser vermiştir. Bahsita'da H.1311/M.1893-94'te açılan Davudiye matbaasının imtiyaz sahibi Haham Şaban Efendi'dir ve İbranice dilinde yayın yapmışlardır. Tüm matbaalar taş ve harufat türünde basım yapmış olmakla beraber resim basmaları yasaklanmıştır.

\section{Tartışma}

Alan yazın incelendiğinde Halep'in eğitim tarihi ile ilgili sınırlı sayıda çalışma mevcuttur. Bunların içinden Görür (2016)'ün Halep'teki eğitim-öğretim kurumları ile ilgili yayınlamış olduğu makalede 1898-1907 yılları arasında idadîde okutulan dersler, idareciler ve öğretici kadrosuna bakıldığında tek bir tablo yaptığı ve tüm yıllarda aynı derslere aynı hocaların girdiği, idarecilerin değişmediği yargısı çıkmaktadır. Fakat 1898-1904 yıllarını kapsayan bu çalışmada durumun böyle olmadığı yıllara göre hocaların değiştiği, bazı derslerin eklenip, bazılarının başka derslerle birleştirildiği gözlemlenmiş̧ir. Ayrıca H.1321/M.1904 yılına ait salnâmede ziraat, hayvanat ve nebatat ile ilgili derslerin hiçbirine çalışmada yer verilmemiştir. Matbaaların resim basma imtiyazı olmadığı bilgisine de değinilmemiştir. Makale de "1907 Maârif Salnâmesi" diye bir ibare bulunmakta olup son Maârif Salnâmesi gerçekten H.1325/M.1907-1908 yılına ait olmakla beraber bu ve H.1320/M.1903 tarihli salnâmelere günümüzde ulaşılamamıştır. Araştırmacı tarafından H.1321/M.1904 tarihi yanlış çevrilerek 1907 olarak ele alınmıştır. 1904'ten sonra eğitim hakkındaki bilgilere vilâyet salnâmelerinden ulaşılmaktadır. Ayrıca Osmanlıca'dan Türkçeye yapılan çevirilerde (Hasan=Hüsnü, Fethullah=Fettah, Rıfat= Refet, Haçadur $=$ Haçador, İsmetullah=İsmetah, Abdi=Abdah, Harufat $=$ Hurufat gibi) yanlış çeviriler mevcuttur. Yaslıçimen (2018)'in yazdığ 1 Halep Mekteb-i İdadisi (1898-1918) adlı tezde ise H.1321/M.1904'te okutulan bazı derslerin tam adı verilmemiş olup Ziraat mübaşiri dersine hiç yer verilmediği de görülmektedir. Bu bağlamda 1900-1901'de Mubassır görevinde bulunan Emir Vasfi Efendi'nin adının Ömer Vasfi; 1904'te ise bu vazife için görevli olan Habib Efendi'nin İbrahim olarak okunduğu dikkat çekmektedir. Bu okumanın Ömer olarak yapılabilmesi için vav harfinin olmasi gerekmektedir.

\section{Sonuç ve Öneriler}

Halep Sancağı'nda bir adet idadi, Ferat gazetesi ve resmi, Maruni, Davudiye olmak üzere üç adet matbaa mevcuttur. Resmi matbaa ve gazete Arapça-Türkçe, Marûni matbaası Türkçe, Davudiye matbaası İbranice dilinde eser neşretmiş olup matbaaların hepsinin taş ve harufat basımına izni vardır. Fakat resim basılması yasaktır. Bu durum bölgenin hassasiyetinden kaynaklanmaktadır. Marûni matbaası İlyas Hekim, Davudiye matbaası Haham Şaban adına 
imtiyaza sahiptir. İdadide Türkçe, Arapça, Farsça, Ermenice ve Fransızca dil eğitimi verilmektedir. Halep Mektep İdadisin'de 1898'de 114 Müslim, 7 Gayrimüslim; 1899'da 107 Müslim, 8 Gayrimüslim; 1900'de 141 Müslim, 11 Gayrimüslim; 1901'de 197 Müslim, 11 Gayrimüslim; 1904'te 233 Müslim, 11 Gayrimüslim öğrenci eğitim görmüştür. İdadi de H.13181319/M.1900-1901 yıllarında 8, H.1317/M.1899 ve H.1321/M.1904 yıllarında 9 hademe görev yapmış fakat H.1316/M.1898'de hademe sayısı belirtilmemiştir. 1898-1904 yılları arasında Halep Mekteb İdadisinde Kitabet Resmiye, Cebir, Kavanin, Türkçe, Servet, Edebiyat, Fransızca, Arapça, Ulum-i diniye, Kimya, Hikmet, Hıfzüllsıhha, Hesap ilmi, İlm-i Eşya, Kozmoğrafya, Mevalid, Müsellesat, Makine, Malumat Nafia, Ahlak, Usul Defteri, Tarih, Coğrafya, Akaid, Fıkıh, Farsça, İnşa, Kitabet, Hendese, Hüsnühat, Ermenice, Resim, Mekanik, Müsellesat, Ziraat dersleri ve ameliyat ziraiye, Malumatı Ziraîyye, İlmi servetin ziraate tatbiki, ziraat makineleri ve nebatat-1 ziraiye, hayvanatı ziraiye, zirai usul defteri, Mevalid-i Salis derslerinin öğretimi gerçekleştirilmiştir.

Halep'te 16 kütüphane, bu kütüphanelerde toplam 8.027 kitap bulunmaktadır. Bunların arasında 1.467 kitap ile en çok kitaba sahip kütüphane Ahmediye iken 21 kitapla en az kitap bulunan kütüphane ise Karnahiye kütüphanesidir. Ayrıca sancakta 21 medrese mevcut olup en fazla öğrenciye sahip medreseler Camii Kebir beni işla ve Osmaniye medreseleri iken en az öğrencisi olan Sultaniye, Hüsreviye, Mansuriye medreseleridir. 1899 yılında Camii Kebir ben-i işla medresesinin müderrisi olmadığı için o sene bir öğrenciye sahip iken sonraki yıllarda öğrenci sayıs 220 ile 200 arasında değişkenlik göstermiştir. Ahmediye medresesi 4 müderris ile en fazla müderrise sahip olan medresedir. Medreseler ağırlıklı olarak Karakara ve Suyukta Hanım mevkilerinde inşa edilmiştir. Hacı Musa, Seydiye, Eşrefiye, Muytab Ahmed Paşa, Cami Kebir, Cami Kebir ben-i aşli, Adliye ve Hüsreviye medreselerinin y1llara göre müderrisleri ve kurucu isimleri değişiklik göstermiştir. Müderrislerin değişiklik gösterme durumu tayin, emekli olma ve vefat gibi nedenlere bağlı olduğu söylenebilir. Caferiye medresesinin müderrisi aynı olmakla birlikte 1899 yılında kurucusu Eşref Efendi olarak zikredilirken 1900-1904 yılları arasında Evkaf Hümayun olarak belirtilmiştir. Seydiye medresesinin kurucusu 1899'da Emeviye'den Sultan Abdülmelik olarak belirtilirken 1900-1904 arası meçhul olarak belirtilmiştir. Hüsreviye medresesinin 1899'da kurucusu Na'malum (belirsiz) olarak ifade edilirken 1900-1904 arasında kurucusunun Hüsrev Paşa olduğu bilgisi mevcuttur. Medrese kurucularının yıllara göre değişiklik göstermesi ilk kurucularının vefat edip sonra yerine vekilinin geçmiş olabileceğini düşündürmektedir.

Alanda konu ile ilgili çok fazla çalışma yapılmamış olmasına rağmen yapılan tez ve makale araştırmalarında, araştırmacıların yanlış bilgilendirmelere sebebiyet vermemesi için Osmanlıca metinlerin çevirisine dikkat etmeleri önerilebilir.

Çeviri gerektiren bilimsel faaliyetlerin çevirilerinin aslına uygunluğunu kontrol edecek akademik çeviri kurulları oluşturulabilir.

Yapılan her türlü akademik eserin yayınlanmadan önce bir komisyon tarafindan detaylı incelemeye tabiî tutulması güvenilir bilgi kaynaklarına erişim açısından fayda sağlayabilir.

Öğrencilerde ahlaki muhakeme yeteneğinin kazandırılması için eskiden olduğu gibi Ahlak/Etik adı altında doğrudan değer öğretimini konu alan seçmeli dersler müfredata eklenebilir.

Halep İdadisi'nin 300 öğrenciye eğitim verecek kapasitede tasarlandığı halde en fazla 1904 y1lında 233 öğrenciye öğrenim verdiği dikkate alınarak günümüzde eğitim-öğretim faaliyetlerine devam eden okulların öğrenci sayısı çok fazla olmamakla beraber belli bir kontenjanı olması ve bunun altında öğrenci alınmasının eğitimin kalitesini ve öğrenciye yönelik birebir eğitim imkanını arttırması ön görüldüğünden önerilmektedir. 


\section{Kaynakça}

Akyüz, Y. (2019). Türk eğitim tarihi (M.Ö. 1000- M.S. 2018). (30. Bask1). Ankara: Pegem Akademi Yayıncılık.

Babuçoğlu, M., Eroğlu, C. ve Köçer, M. (2007). Osmanlı vilâyet salnâmelerinde Halep. Global Strateji Enstitüsü, Ankara: Kozan Ofset.

Baltac1, C. (2002). Osmanl devletinde eğitim ve öğretim. Türkler. c.11, ss. 456. Ankara: Yeni Türkiye Yayınları.

Bayraktar, H. (2004). XIX. yüzyılda Halep eyaletinin iktisadi vaziyeti. Firat Üniversitesi, Orta Doğu Araştırmaları Merkezi Yayınları No.8. Tarih Şubesi Yayınları No.7. Elazı̆̆.

Brocekelman, C. (1992). İslam uluslarl ve devletleri tarihi (N. Çağatay, Çev.). Atatürk Kültür, Dil ve Tarih Kurumu, Ankara: Türk Tarih Kurumu Yayınları.

Büyüköztürk, Ş. Çakmak, E. K. Akgün, Ö. E. Karadeniz, Ş. ve Demirel, F. (2012). Bilimsel araştırma yöntemleri. Ankara: Pegem Akademi Yayınları.

Çakar, E. (2003). XVI. yüzyıl da Halep sancağı (1516/1566). Elazığ: Fırat Üniversitesi Ortadoğu Araştırmaları Merkezi Yayınları.

Çakar, E. (2006). XVII. yüzyılda Halep eyaleti ve Türkmenleri. Firat Üniversitesi, Elazığ: Orta Doğu Araştırmaları Merkezi Yayınları, No.13, Tarih Şubesi Yayınları, No.11.

Düvenci Karakoç, F. (2013). XIX. Yüzyıl sonunda Halep'te İngiliz belgelerine göre toplum, yönetim ve konsoloslar arasındaki ilişkiler. Uludă̆ Üniversitesi Fen Edebiyat Fakültesi Sosyal Bilimler Dergisi, 24, 68-90.

Dönmez, C., Akyol, C. (2017). A Critical Approach for the Values Education in Social Studies, IJOESS, 8, 30, 1396-1415.

Ekiz, D. (2013). Bilimsel araştırma yöntemleri (yaklaşım, yöntem ve teknikler). (3. Baskı). Ankara: Anı Yayıncilik.

Ergin, O. (1977). Türk maârif tarihi C.1-2. İstanbul: Eser Matbaas1.

Elhem, E. Goffman, D. ve Masters, B. (2003). Doğu ile Batı arasında Osmanlı kenti (Halep, İzmir ve İstanbul) (S.Yalçın, Çev.). İstanbul: Tarih Vakfı Yurt Yayınları.

Ethem, H. (1927). Düvel-i İslamiye. İstanbul: Devlet Matbaas1.

Görür, E. (2016). Maârif ve vilâyet sâlnâmelerine göre Halep vilâyetinde eğitim öğretim kurumları. Uluslararası Sosyal Araştırmalar Dergisi, (9), 424-431.

Göyünç, N. (1975). XVI. yüzyılda güneydoğu Anadolu'nun ekonomik durumu (Kanuni ve II. Selim devirleri). Türkiye İktisat Tarihi Semineri, Metinler Tartışmalar, 8-10 Haziran 1973, Ankara.

Grausset, R. (1980). Bozkır imparatorluğu (N. Çağatay, Çev.). (1. Baskı). İstanbul: Ötüken Yayınları.

Halaçoğlu, Y. (1997). XVIII. yüzyılda Osmanlı imparatorluğunun iskân siyasetleri ve aşiretlerin yerleştirilmesi. Atatürk Kültür, Dil ve Tarih Yüksek Kurumu, Ankara: Türk Tarih Kurumu Yayınlar1.

Hayta, S. (1995). 1869 Maârif-i Umumiye Nizamnamesi ve Türk eğitimine katkıları (Yayınlanmamış yüksek lisans tezi). Gazi Üniversitesi, Ankara.

Heyd, W. (2000). Yakın-doğu ticaret tarihi (E. Z. Karal, Çev.). Ankara: Türk Tarih Kurumu Basımevi. 
Iş1ltan, F. (1966). Seyfüd-Devle. İslam Ansiklopedisi, (X), 536-539 İstanbul: Milli Eğitim Yayınları.

İnalcık, H. (2008). Türkiye tekstil tarihi üzerine araştırmalar. İstanbul: Türkiye İş Bankası Yayınları.

İpşirli, M. (2003). Medrese. Íslam Ansiklopedisi (DİA), (28), 338-340 İstanbul: TDV Yayınları.

Kılıç, R. (2016). XIX. Yüzyılda Halep vilâyeti idaresi. Erciyes Aylık Fikir ve Sanat Dergisi, (39), 14-19.

Koçer, H. A. (1991). Türkiye'de modern ĕgitimin doğuşu ve gelişimi. İstanbul: Milli Eğitim Bakanlığı.

Kodaman, B. (1980). Abdülhamit devri eğitim sistemi. İstanbul: Ötüken Yayınları.

Köprülü, F. (1961). Baybars. İslam Ansiklopedisi, (2), 357-365 İstanbul: Milli Eğitim Yayınları.

Krenkow, F. (1993). Kütüphâne. İslam Ansiklopedisi, (6). İstanbul: Milli Eğitim Yayınları.

Lammens, H. (1970). Suriye. İslam Ansiklopedisi, (11), ss.52. İstanbul: Milli Eğitim Yayınları.

Margosyan, M. (2017). Gâvur mahallesi. (20. Baskı). İstanbul: Aras Yayınc1lı.

Merçil, E. (1997). Müslüman Türk devletleri tarihi. (3. Bask1). Ankara: Türk Tarih Kurumu Basimevi.

Pakalın, M. (1983). Tarih Deyimleri ve Terimleri Sözlüğü. İstanbul: Milli Eğitim Yayınları.

Palalı, İ. (2010). Osmanlı Salnâmeleri ve tarih araştırmalarındaki kaynak olarak önemi. Harran Üniversitesi Illahiyat Fakültesi Dergisi. 23 (Ocak-Haziran), 1-14.

Paşa, C. (1991). Tezâkir 21-39 (III) (C. Baysun, Çev.), (3. Baskı). Ankara: Türk Tarih Kurumu Basimevi.

Raymond, A. (1995). Osmanlı döneminde Arap kentleri (A. Berkay, Çev.), İstanbul: Türkiye Ekonomik ve Toplumsal Tarih Vakfı Yayınları.

Salnâme-i Nezâret-i Maârif-i Umûmiyye H.1316 (M.1898), Sene 1316, Def'a 1, İstanbul: Matbaai Âmire.

Salnâme-i Nezâret-i Maârif-i Umûmiyye H.1317 (M.1899), Sene 1317, Def'a 2, İstanbul: Matbaai Âmire.

Salnâme-i Nezâret-i Maârif-i Umûmiyye H.1318 (M.1900), Sene 1318, Def'a 3, İstanbul: Matbaai Âmire.

Salnâme-i Nezâret-i Maârif-i Umûmiyye H.1319 (M.1901), Sene 1319, Def'a 4, İstanbul: Matbaai Âmire.

Salnâme-i Nezâret-i Maârif-i Umûmiyye H.1321 (M.1904), Sene 1321, Def'a 6, İstanbul: Asır Matbaas1.

Salnâme-i Vilâyet-i Halep, D02458130300000015. (ISAM)-1303.

Salnâme-i Vilâyet-i Halep, D02458131200000023. (ISAM)-1312.

Salnâme-i Vilâyet-i Halep, D02458131200000025. (ISAM)-1314.

Sami, Ş. (1998). Kamus-u Türki. İstanbul: Alfa Yayınları.

Sami, Ş. (1306). Kâmûsu'l-âlâm. İstanbul: Alfa Yayınları.

Sauvaget, J. (1967). Halep. İslam Ansiklopedisi, V/I, 117-122 İstanbul: Milli Eğitim Yayınları.

Sêdillot, R. (2005). Dünya ticaret tarihi (E. N. Erendor, Çev.). Ankara: Dost Kitabevi. 
Tansel, S. (1969). Yavuz Sultan Selim. Ankara: Milli Eğitim Basımevi.

Tutar, A. (2010). XIX. Yüzyılın ikinci yarısında Halep şehrinin kültürel yapısı, Fırat Üniversitesi Illahiyat Fakültesi Dergisi, 21-31.

Oğuzoğlu, Y. (2009). Hint-Basra mallarının Akdeniz ticaretine aktarımı: İskenderun ve Payas limanlarl (XVI-XVIII yüzylllar). Türk Deniz Ticaretini Tarihi Sempozyumu I, (İzmir ve Doğu Akdeniz), 110-127.

Ostrogorsky, G. (1986). Bizans devleti tarihi (F. Işıltan, Çev.). Ankara: Türk Tarih Kurumu Basımevi.

Öztürk, M. (1997). 1616 tarihli Halep avazız hane defteri, htpp://dergiler.ankara.edu.tr/dergiler/19/868/11026.pdf. 249-293.

Öztürk, C. (2000). İdadî. TDV İslam Ansiklopedisi (DİA), (XXI). İstanbul: TDV Yayınları.

Umar, O. (2003). Türkiye-Suriye ilişskileri 1918-1940. Elazığ: Fırat Üniversitesi Yayınları.

Umar, O. (2004). Osmanl yönetimi ve Fransız manda idaresi altında Suriye 1908-1938. Ankara: Atatürk Araştırma Merkezi.

Uzunçarşı11, İ. H. (1975). Osmanlı tarihi. (II). (3. Baskı). Ankara: Türk Tarih Kurumu Basımevi.

Uzunçarşı11, İ. H. (2014). Osmanlı Devleti'nin ilmiye teşkilatı. Ankara: TTK.

Yaslıçimen, S. (2018). Halep Mekteb-i İdadîsi (1888-1918) (Yayınlanmamış yüksek lisans tezi). Fatih Sultan Mehmet Vakıf Üniversitesi, İstanbul.

Yazıc1, T. (1997). Halep. TDV İslam Ansiklopedisi (DİA), (15), 239-242 İstanbul: Türkiye Diyanet Vakfı Yayınları.

\section{ETIKK ve BİLIMSEL İLKELER SORUMLULUK BEYANI}

$\mathrm{Bu}$ çalışmanın tüm hazırlanma süreçlerinde etik kurallara ve bilimsel atıf gösterme ilkelerine riayet edildiğini yazar(lar) beyan eder. Aksi bir durumun tespiti halinde Afyon Kocatepe Üniversitesi Sosyal Bilimler Dergisi'nin hiçbir sorumluluğu olmayıp, tüm sorumluluk makale yazarlarına aittir.

\section{ARAŞTIRMACILARIN MAKALEYE KATKI ORANI BEYANI}

1. yazar katk1 oran1: $\% 75$

2. yazar katk1 oranı: $\% 25$ 